
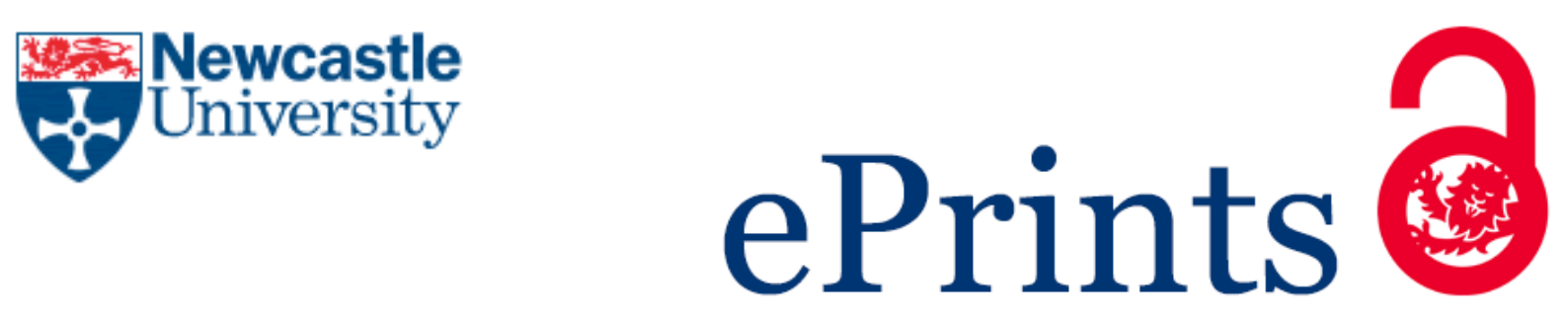

Christensen P, Mashhadani Z, MdAli AHB, Carroll M, Martin P.

The Production of Methane, Acetone, "Cold" CO and Oxygenated Species

from Isopropyl Alcohol in a Non-Thermal Plasma: An In-Situ FTIR Study.

The Journal of Physical Chemistry 2018, 122(17), 4273-4284.

\title{
Copyright:
}

This document is the Accepted Manuscript version of a Published Work that appeared in final form in The Journal of Physical Chemistry, copyright @ American Chemical Society after peer review and technical editing by the publisher. To access the final edited and published work see https://doi.org/10.1021/acs.jpca.7b12297

Date deposited:

$03 / 05 / 2018$

Embargo release date:

17 April 2019 
This document is confidential and is proprietary to the American Chemical Society and its authors. Do not copy or disclose without written permission. If you have received this item in error, notify the sender and delete all copies.

\section{The Production of Methane, Acetone, "Cold" CO and Oxygenated Species from Isopropyl Alcohol in a Non- Thermal Plasma: An In-Situ FTIR Study}

\begin{tabular}{|r|l|}
\hline Journal: & The Journal of Physical Chemistry \\
\hline Manuscript ID & jp-2017-12297z.R2 \\
\hline Manuscript Type: & Article \\
\hline Date Submitted by the Author: & $\mathrm{n}$ /a \\
\hline Complete List of Authors: & $\begin{array}{l}\text { Christensen, Paul; Newcastle Univ, School of Engineering } \\
\text { Mashhadani, Zeinab; Newcastle Univ, School of Engineering } \\
\text { Md Ali, Abd Halim Bin; Newcastle University, School of Engineering } \\
\text { Carroll, Michael; Newcastle Univ, School of Natural and Environmental } \\
\text { Sciences } \\
\text { Martin, Philip; University of Manchester, School of Chemical Engineering \& } \\
\text { Analytical Science }\end{array}$ \\
\hline
\end{tabular}

SCHOLARONE

Manuscripts 


\title{
The Production of Methane, Acetone, "Cold" CO
}

\section{and Oxygenated Species from IsoPropyl Alcohol in}

\section{a Non-Thermal Plasma: An In-Situ FTIR Study}

\author{
Paul A. Christensen ${ }^{*}$, Z. T. A. W. Mashhadani ${ }^{a}$, Abd Halim Bin Md Ali $^{a}$, Michael A. Carroll ${ }^{b}$ \\ and Philip A. Martin ${ }^{c}$ \\ ${ }^{\text {a }}$ School of Engineering, Bedson Building, Newcastle University, Newcastle upon Tyne, UK, \\ NE1 7RU \\ ${ }^{\mathrm{b}}$ School of Natural and Environmental Sciences, Bedson Building, Newcastle University, \\ Newcastle upon Tyne, UK, NE1 7RU
}

${ }^{\mathrm{c}}$ School of Chemical Engineering and Analytical Science, The University of Manchester, Oxford Road, Manchester, M13 9PL 


\begin{abstract}
This paper reports in-situ Fourier Transform InfraRed (FTIR) spectroscopic studies on the non-thermal plasma reaction of isopropyl alcohol in dinitrogen at Macor (a ceramic containing oxides of $\mathrm{Al}, \mathrm{Mg}$ and $\mathrm{Si}$ ) and the analogous thermally-driven process. Whilst isopropyl alcohol did not react at the Macor at temperatures up to $600^{\circ} \mathrm{C}$, the study of the nonthermal plasma-driven process at the ceramic led to unexpected chemistry hitherto not observed, primarily the reaction of IPA in dinitrogen at short timescales to produce methane, HCN, acetone and "cold" $\mathrm{CO}$ at ca. $115 \mathrm{~K}$. The $\mathrm{CO}$, methane and $\mathrm{HCN}$ rapidly established steady state concentrations, pointing to the need for faster FTIR studies: at longer times, isophorone and a "polymethylacetylene-like" polymer were formed as a brown oil. The observation of the steadystate gases and brown oil suggested parallel pathways in the plasma, the latter taking place at the plasma/catalyst interface, and the former in the plasma remote from the catalyst. Replacing dinitrogen with argon completely inhibited or negated the production of the oil, had no effect upon the processes taking place in the plasma remote from the Macor and instead resulted in the production of acetylene.
\end{abstract}

\title{
1. Introduction
}

\section{Non-thermal plasma}

Plasma is widely regarded as the fourth state of matter and is characterized by the presence of atoms, molecules, ions, electrons and radicals having internal energies (with the exception of the electrons) unevenly distributed over the three degrees of freedom. ${ }^{1}$ The dielectric barrier discharge reactors typically utilising Non Thermal Plasmas (NTPs) generally consist of two electrodes across which is a pulsed or AC high voltage field separated by one or more dielectric 
layers. In such plasmas, the temperature of the electrons is as high as $10^{3}-10^{4} \mathrm{~K}$, whilst the heavier species remain around ambient temperature. ${ }^{2}$

\section{The role of the dielectric and catalyst in a non-thermal plasma}

Initially, the gap between the two high voltage electrodes in NTP reactors was packed with dielectric pellets such as $\mathrm{Al}_{2} \mathrm{O}_{3}$ or $\mathrm{BaTiO}_{3}$ and these were employed simply to increase the nonuniformity of the electric field so that there are regions of much higher electric field than the applied field thus leading to more energetic electrons. The discharge current I as described by the Manley equation: ${ }^{3}$

$$
\mathrm{I}=4 f \mathrm{C}_{\mathrm{d}}\left(\mathrm{V}-\mathrm{V}_{\mathrm{o}} \mathrm{C}_{\mathrm{g}} / \mathrm{C}\right)
$$

where $f$ is the discharge frequency, $\mathrm{C}_{\mathrm{d}}$ is the dielectric capacitance, $\mathrm{C}_{\mathrm{g}}$ is the capacitance of the background gas within the discharge gap, $\mathrm{V}_{\mathrm{o}}$ is the discharge onset voltage and $\mathrm{V}$ is the discharge voltage $(\mathrm{kV})$. It was then found that certain dielectrics could also act as catalysts, steering the reaction to yield different products with different catalysts (e.g. $\mathrm{Ni} / \mathrm{SiO}_{2}{ }^{4}, \mathrm{NiO} / \mathrm{WO}_{3}$ vs Faujasite vs Mordenite ${ }^{5,6}$ ) but the trends observed when using a range of such catalysts are simply not understood. ${ }^{4,7,8}$ Consequently, this led to catalyst selection for NTP processes being based on identifying those materials that are active for the same chemical processes when carried out in conventional, thermal reactors operating under steady state conditions; however plasmas are most certainly not in a steady state and such materials are generally found not to be especially catalytic in NTP systems. 


\section{The potential advantages of plasma catalytic chemistry}

The ions, radicals and vibrationally electronically excited species produced through the collisions between the high energy electrons generated in the NTP are only observed at temperatures $>1000 \mathrm{~K}$ in thermal systems. ${ }^{9}$ In addition, the vibrationally excited species present in NTPs, and essentially unavailable in thermal systems, can exhibit enhanced sticking probabilities at catalyst surfaces and hence enhance the reactivity of endothermic processes., ${ }^{9,10}$ Thus the key advantage of non-thermal plasma chemistry is that it makes a range of chemistries viable, where, by conventional means, they would require extremes of temperature and/or pressure that would be technically challenging and economically unfeasible. In addition, in principle, almost $97 \%$ of the plasma discharge power of low temperature plasmas can be converted into vibrational excitation of the gas feed molecules. ${ }^{11}$ In summary, coupling NTP with catalysts offering novel chemical pathways with lower activation energies opens up the potential for a wholly new and exciting field of chemistry. In addition, it should be possible to enhance targeted reactions and suppress others by appropriate choice of catalyst, and feed gas, by controlling the number density of electrons and controlling the temperatures of the electrons and gaseous species.

A significant challenge of NTP-driven systems is perceived to be the high energy demand; however, companies such as Siemens (private communication) have adopted strategies involving the harnessing of the spillover of renewably-generated electricity to the production of fuels and chemical products as matching the production of electricity from renewable energy to demand is very difficult, and often the surplus is simply spilled. The storage of this surplus energy chemically is seen as a possible solution to this problem; for example, the plasma-driven 
reduction of $\mathrm{CO}_{2}$ to $\mathrm{CO}$ and $\mathrm{O}_{2}$ is perceived as one possible chemical process, particularly as some industrial plants produce almost pure $\mathrm{CO}_{2}$ as waste gas. ${ }^{12}$ There could also be environmental benefits associated with plasma technology: thus, Martuzevicius and co-workers ${ }^{13}$ compared conventional technologies with plasma systems for the destruction of volatile organic compounds, and found that NTP-based technology performed better with respect to the ozone layer depletion, acidification, eutrophication and human toxicity potential. The authors reported that "The relatively high demand of electrical energy causes lower positioning of plasma technologies in cases where no other materials are utilized and major waste is formed. On the other hand, many traditional end-of pipe technologies are associated with high amounts of process waste, which provides plasma technologies with an opportunity to establish them in the market as more efficient and in many occasions, more environment-friendly ones".

Finally, as discussed below, plasma catalysis has not been researched sufficiently to exploit its very real potential.

\section{A summary of the applications of non thermal plasma}

There are many companies producing commercial non-thermal plasma systems across a range of applications and these include: Enercon, Alternor, Plasma Etch, AcXys (surface treatment/etching) and Ozonia, Lenntech and Evoqua (ozone for water treatment). Further, electrostatic precipitation for industrial separation and gas cleaning dates back to $1907^{14}$; however, none of these commercial systems rely upon plasma catalysis. 
In the laboratory, topical chemical conversions using NTPs include ${ }^{15}$ : ozone generation ${ }^{16}$, the conversion of $\mathrm{CH}_{4}$ to $\mathrm{H}_{2}$ and $\mathrm{C} 2-\mathrm{C} 4$ derivatives ${ }^{17}$, toluene to phenol and cresols ${ }^{5}, \mathrm{CO}_{2}$ and $\mathrm{H}_{2} \mathrm{O}$ to syngas and synfuels ${ }^{18}$, the treatment of Volatile Organic Compounds ${ }^{19}$, decontamination and disinfection $^{20}$, the deep desulfurization of diesel fuels ${ }^{21}$, the treatment of flue gas ${ }^{22}$ and the dry reforming of $\mathrm{CO}_{2}$ and $\mathrm{CH}_{4}{ }^{23}$

Typically, the reactors employed in the above systems are based on cylinders of $\mathrm{Al}_{2} \mathrm{O}_{3}$ or quartz with one high voltage electrode wrapped around the outer surface of the cylinder and a metal rod, mounted along the axis of the cylinder, as the second electrode. ${ }^{24-26}$ Where catalyst pellets are used packed bed reactors are generally employed. ${ }^{25}$

\section{The challenges facing the exploitation of plasma catalytic chemistry}

As stated above, the potential of NTP-assisted catalysis in chemical synthesis is as yet largely unrealized: this is most likely due to the lack of analytical information on the processes taking place at the catalyst/plasma interface (interestingly, the US Plasma 2010 Committee report $^{27}$ concluded that the interactions of plasmas with solid surfaces is one of the six critical challenges that define the plasma research frontier; a view that is still extant today). Hence the chemical mechanisms and kinetics involved are simply not understood. ${ }^{28,29}$ This is reflected in the paucity of catalyst selection as discussed above and the simplicity (and unoptimised nature) of NTP reactor design. ${ }^{9,11}$

As stated above, NTP reactors utilising catalyst are most commonly of the packed-bed type, either as a variant of the tube reactors described above with the gap filled with the 
catalyst/dielectric pellets or two plate electrodes separated by a gap filled with pellets. ${ }^{10}$ It is not at all clear these configurations are optimum, as there is no theoretical basis for their design: such a basis requires the chemistry taking place in the reactor to be modelled. All designs so far have essentially been empirical; they have not as yet been formulated on the basis of known or estimated rate constants or reaction mechanisms. The interaction of highly excited and reactive species with solid surfaces is largely unknown both in terms of the chemistry and the timescale over which such reactions take place. ${ }^{9}$ Furthermore, whilst the potential synergy between NTP and catalysis is widely acknowledged in the NTP community, it has not been possible to include catalysis in models: indeed, even accounting for chemical reactions on the chemically simple surfaces of the HV electrodes has proven too challenging ${ }^{30}$ due to the lack of chemical information on the species present. For example, in the absence of information on the identities of the species present in non-thermal plasmas, and at the solid (dielectric/catalyst)/plasma interface, all possible species need to be included in the model (e.g. up to 150 molecules ${ }^{31,32}$ ) which increases computing time and decreases the accuracy of the model. Our previous FTIR research strongly suggests that it should be possible to provide the hard experimental data required to aid effective modelling and hence reactor design. ${ }^{33}$

\section{The plasma-driven conversion of isopropyl alcohol at Macor}

The overall aim of the NTP work in Newcastle is to study plasma catalytic processes by employing in-situ infrared spectroscopy to probe the plasma glow region (the region of the plasma that emits the characteristic blue/white glow) and the plasma/catalyst interface, and hence determine the mechanisms of such processes. This information will then be compared to data obtained using a Specac Environmental Chamber and Diffuse Reflectance InfraRed 
Spectroscopy attachment ${ }^{34}$ allowing the catalyst to be monitored in-situ using diffuse reflectance IR spectroscopy at temperatures up to $600{ }^{\circ} \mathrm{C}$. The same reactants and catalysts will be studied in both systems. Hence Macor was chosen as the catalyst for our initial studies as it has both a reasonable dielectric constant (ca. 6) and high thermal stability. ${ }^{35}$ The Macor was not characterized as it is produced only in pellet form which is extremely hard and hence it has not proved possible to produce contaminant-free powder for, for example, XRD or XPS by filing etc.

The initial system chosen for comparative study was IsoPropyl Alcohol (IPA) for two reasons: (1) its relevance to the study of the removal of Volatile Organic Compounds (VOCs) from air. IPA is a routinely-employed solvent in the electronics industry and, as such, a number of studies have been reported in the literature on the removal of this Volatile Organic Compound (VOC) from air using NTP-assisted catalysis. ${ }^{36-38}$ (2) We already have IR data on the thermal behaviour of $\mathrm{SnO}_{2}{ }^{34}$, and there is a wealth of IR data in the literature on the interaction of IPA with oxide surfaces under thermal conditions, see for example. ${ }^{39-46}$ The carrier gas employed in the studies reported in this paper was nitrogen rather than air in order to start with the simplest system comprising only two components.

\section{The state-of-the-art in in-situ FTIR studies of non-thermal plasmas}

Whilst the plasma/catalyst surface has not been investigated extensively with in-situ infrared spectroscopy, such studies have started to appear, There are a number of studies on the downstream analysis of the exhaust from NTPs, see for example ${ }^{47}$, but actual studies of the plasma glow with IR spectroscopy ${ }^{33}$ or of the catalyst surface in contact with a plasma is only a recent phenomenon. ${ }^{48-53}$ The quality of the information that can be obtained from in situ FTIR is 
exemplified by the work of Li and co-workers on the deposition of Si from hexamethyldisiloxane plasma ${ }^{49}$, Rivallan and colleagues on the conversion of IPA at $\mathrm{Al}_{2} \mathrm{O}_{3}{ }^{48}$, Stere et al. ${ }^{50}$ on the hydrocarbon assisted NOx removal from simulated diesel fuel over silver-based catalysts, Rodriguez et al. ${ }^{51}$ on the conversion of IPA at $\mathrm{Al}_{2} \mathrm{O}_{3}, \mathrm{CeO}_{2}$ and $\mathrm{TiO}_{2}$ and $\mathrm{Jia}$ and Rousseau on the plasma-assisted reaction of acetone at $\mathrm{CeO}_{2}{ }^{52}$. These studies employed the Diffuse Reflectance approach ${ }^{50,51}$, transmission through the catalyst as a wafer ${ }^{48,52}$ or passed the IR beam through the plasma glow above the solid surface ${ }^{47,49}$. Rivallan and co-workers ${ }^{53}$ employed the step scan approach to study the gas phase reduction of $\mathrm{CO}_{2}$ in a tube reactor (i.e. they did not study the catalyst/plasma interface): however, they saw no reaction products or intermediates, although the authors did achieve a time resolution of ca. $400 \mu \mathrm{s}$.

In general, and even in the presence of ozone ${ }^{54}$, the plasma-driven catalysed conversion of IPA generally leads to toxic products such as acetone and mesityl oxide rather than complete conversion to $\mathrm{CO}_{2}$, and hence the requirement for effective catalysts is clear.

\section{Justification for the work}

The preliminary work reported in this paper seeks to determine, compare and contrast the mechanisms of the plasma catalytic and thermal catalytic conversions of IPA at Macor as a first step in understanding the chemistries taking place at the plasma/catalyst surface with the ultimate aim of devising appropriate, optimum catalysts to realize the potential of NTP-assisted catalysis. 


\section{Experimental}

Isophorone (3,5,5-trimethyl-2-cyclohexen-1-one, 97\%) and isopropyl alcohol (99.5\%) were supplied by Sigma Aldrich and used without further purification. Nitrogen gas was supplied via cryogenic boil-off.

IR spectra of liquid isopropyl alcohol and isophorone were obtained using a Presslok holder (Thermo Scientific); ca. $50 \mu \mathrm{L}$ of the liquid was placed between two $25 \mathrm{~mm}$ dia. $2 \mathrm{~mm}$ thick $\mathrm{CaF}_{2}$ windows (Crystran) in the holder.

\section{The non-thermal plasma infrared cell}

The non-thermal plasma infrared cell, see Figure S1, was designed and fabricated in-house and was made from a $15 \mathrm{~cm}$ long, cylindrical polyteTraFluoroEthylene (PTFE) tube with an outer diameter of $6.3 \mathrm{~cm}$ and an inner diameter of $2.5 \mathrm{~cm}$. The high voltage electrodes were in the form of two plungers, sealing against the inner walls of the PTFE via rubber ' $O$ ' rings. One plunger was hollow down its axis (a $5 \mathrm{~mm}$ diameter hole) and the feed gas was delivered via this channel and removed via an outlet nozzle in the top of the cell. The electrodes were covered with $5 \mathrm{~mm}$ thick Macor caps fitted snugly over each disc electrode, with a hole aligned with the central, gas delivery channel. Two infrared transparent $\mathrm{CaF}_{2}$ windows $(25 \mathrm{~mm}$ diameter, $3 \mathrm{~mm}$ thick, Crystran) were glued into the PTFE cell. The distance between the windows (path length) was $5.1 \mathrm{~cm}$. The windows were positioned such that their centres aligned with the centre of the 5 mm gap between the electrodes. The plasma volume was $7.4 \mathrm{~cm}^{3}$ and the residence time at a flow rate of $200 \mathrm{~cm}^{3} \mathrm{~min}^{-1}$ was $2.2 \mathrm{~s}$. 
The electrodes were connected to a NeonPro lamp transformer, NP100000-30 (Hyrite, China) which provided an output up to $10 \mathrm{kV}$ at a constant frequency of $24 \mathrm{kHz}$. A voltage controller (Carroll \& Meynell) was used to control the input power to the HV transformers. The input power to the plasma was monitored using a Gadget 13A (N67FU Maplin, UK) Power Meter; the input powers quoted were those obtained by subtracting the input power observed with plasma from the reading obtained with the system switched on but with no plasma initiated (4 W).

\section{The FTIR plasma system}

An Agilent FTS7000 FTIR spectrometer with a Deuterated Tri-Glycine Sulfate (DTGS) detector was employed. The IR beam was passed through the plasma via the two $\mathrm{CaF}_{2}$ windows to the detector via an Amtir-1 filter, $25 \mathrm{~mm} \times 2 \mathrm{~mm}$ (Spectra-Tech, USA) to remove visible light.

The IsoPropyl Alcohol (IPA) was supplied by Sigma-Aldrich (99.5\%) and used without further purification. Isopropyl alcohol vapour was delivered to the chamber of the reflectance accessory by bubbling nitrogen gas through the alcohol held in a Dreschel bottle. The cell was first flushed with $\mathrm{N}_{2}$ at a flowrate of $200 \mathrm{~cm}^{3} \min ^{-1}$ for 120 minutes; when the system was stable, a background spectrum was collected. $\mathrm{N}_{2}$ was then bubbled through the IPA and admitted to the cell at a total flow rate of $200 \mathrm{~cm}^{3} \mathrm{~min}^{-1}$. A reference spectrum $\left(\mathrm{S}_{\mathrm{R}}, 100\right.$ co-added and averaged scans at $4 \mathrm{~cm}^{-1}$ resolution, 100 seconds per scan set) was collected in the absence of plasma. Sample spectra, $\mathrm{S}_{\mathrm{S}}$, were then taken as a function of time after the high voltage power supply was switched on, and at regular intervals thereafter up to 20 minutes. The spectra are presented as: 


$$
\text { Absorbance, } A=\log _{10}\left(\mathrm{~S}_{\mathrm{R}} / \mathrm{S}_{\mathrm{S}}\right)
$$

These results in difference spectra in which peaks pointing upwards (i.e. to + absorbance) represent a gain in absorbing species at $S_{S}$ with respect to $S_{R}$, and peaks pointing down (to absorbance) represent the loss of absorbing species. In order to remove unchanging absorptions, spectra were subtracted with subtraction factors employed as necessary.

The concentrations of the various species observed were calculated using the Beer-Lambert law:

$$
\mathrm{A}=\varepsilon \mathrm{cL}
$$

where: $\varepsilon$ is the molar decadic extinction coefficient $\left(\mathrm{M}^{-1} \mathrm{~cm}^{-1}\right), \mathrm{c}=$ concentration $(\mathrm{M})$ and $\mathrm{L}=$ optical path length $(5.1 \mathrm{~cm})$. This data manipulation results in difference spectra in which peaks with positive amplitude arise from the gain of absorbing species in $\mathrm{S}_{\mathrm{S}}$ with respect to $\mathrm{S}_{\mathrm{R}}$, and peaks with negative amplitude to the loss of absorbing species.

The temperature of the Macor caps of the transmission cell were monitored at an input power of 27W using a RS-1327 IR Thermometer C infrared thermometer gun in experiments conducted without FTIR data collection (as the cover to the sample compartment had to be removed), the temperature of the Macor caps were found to increase to ca. $43^{\circ} \mathrm{C}$ over 20 minutes. This measurement was not possible with the plasma reflectance cell for safety reasons as the cell could not be manipulated and the thermometer gun would not fit into the sample compartment. 
However, the reflectance cell did employ a cooling gas stream. We have also simulated the absorption band shapes of some of the heavy species in the plasma ${ }^{55}$ and it suggests that the rotational temperatures are usually between ambient and up to around $100^{\circ} \mathrm{C}$ depending on the chemical system, the deposited power and the plasma duration.

We have not observed any problems from the proximity of the high voltage power supply to the FTIR spectrometer: the shielding employed thus appears to work well. Occasionally, we observe "spikes" on the spectra obtained using the reflectance cell, an observation still under investigation, and this was remedied by repeating the experiment.

The spectra presented below were highly reproducible and stable. Essentially the same data were obtained over a number experiments spread over 8 months. For example, as is described in the paper (see figure S7), the experiments were repeated as a function of power, and the same features and species observed, except in varying relative amounts. Again, as is discussed in the paper, the species observed after 1 minute were confirmed (with the exception of $\mathrm{HCN}$ and addition of acetylene) in the Argon experiment which was carried out some 11 months after the initial IPA experiments using nitrogen.

We did not observe any carbon deposits in the plasma experiments on the windows or walls of the cells, or on the Macor; however, this is not to say it does not occur as it may be swept out of the plasma cell by the feed gas. 


\section{The FTIR thermal system}

In-situ FTIR thermal experiments were carried out using a Varian 670-IR spectrometer equipped with a ceramic air-cooled infrared source, a DLaTGS detector and a Specac environmental chamber and diffuse reflectance unit ( $\mathrm{see}^{34}$ for details) with the IR beam reflected from a $12.5 \mathrm{~mm}$ diameter, $2 \mathrm{~mm}$ thick Macor disc. The Specac reflectance accessory allows IR spectra to be collected under controlled atmosphere conditions from room temperature to $600{ }^{\circ} \mathrm{C}$ and pressures from vacuum to $34 \mathrm{~atm}$. The IR beam was incident on the sample in the cell at angles from $20^{\circ}$ to $76^{\circ}$ with respect to the horizontal plane via a $\mathrm{ZnSe}$ window. The same data manipulation was employed as described above in equations (1) and (2).

Water was removed from both the spectrometer purges by a NITROSource generator and to the FTIR cells from a cylinder (N5.5 100\%, BOC). The absence of water from atmosphere of the spectrometer and the cells was confirmed by examining the single beam spectra as well as by following the spectra of the cells as a function of time to check that they were free from water vapour prior to commencing the experiments. Water may have been released from the surface of the Macor during the experiments described below, but there was no direct evidence from the FTIR measurements (distinctive fine structure centred around 3750 and $1640 \mathrm{~cm}^{-1}$ ) to support this release.

\section{Extinction coefficients}

The extinction coefficient of $\mathrm{CH}_{4}$ was determined from measurements using the pure gas in a 1 $\mathrm{cm}$ pathlength cell and is presented in Table 1 along with that of the $3335 \mathrm{~cm}^{-1}$ band of HCN which was estimated from the paper by Choi and Barker. ${ }^{56}$ 
Table 1. The extinction coefficients of various gas phase species. See text for details.

\begin{tabular}{|l|l|l|}
\hline & $\begin{array}{l}\text { Peak } \\
/ \mathrm{cm}^{-1}\end{array}$ & $\varepsilon$ \\
\hline $\mathrm{CH}_{4}$ & 3086 & 3.5 \\
\hline & 1346 & 6.2 \\
\hline $\mathrm{HCN}$ & 3335 & 2.8 \\
\hline
\end{tabular}

We estimate that the detection limit for $\mathrm{CO}$ was ca. $\geq 1.0 \times 10^{-5} \mathrm{M}$ in the thermal cell and a factor of five lower in the plasma transmission cell.

\section{Results and Discussion}

\section{The thermal experiments}

Figure 1 shows spectra collected during an experiment in which a Macor disc was heated from 25 to $600{ }^{\circ} \mathrm{C}$ in an atmosphere of IPA vapour and nitrogen gas. The reference spectrum $\left(\mathrm{S}_{\mathrm{R}}\right)$ was collected at $25{ }^{\circ} \mathrm{C}$ and the temperature then ramped at $5{ }^{\circ} \mathrm{C} \min ^{-1}$, sample spectra $\left(\mathrm{S}_{\mathrm{S}}\right)$ collected at $50{ }^{\circ} \mathrm{C}$ and further spectra collected every $50{ }^{\circ} \mathrm{C}$ up to $600{ }^{\circ} \mathrm{C}$. For clarity, only the spectra collected every $100^{\circ} \mathrm{C}$ are shown.

As can be seen from Figure 1, there are loss features at 3340, 2976, 2887, 1481, 1232, 1007 and $950 \mathrm{~cm}^{-1}$ that increase steadily in intensity as the temperature was increased. In addition, there are loss and gain features between ca. 3600 and $3770 \mathrm{~cm}^{-1}$. The bands between 3600 and $3770 \mathrm{~cm}^{-1}$ and loss features at $3340 \mathrm{~cm}^{-1}, 1481$ and $1232 \mathrm{~cm}^{-1}$ also appear in a repeat of the experiment in Figure 1 in the absence of IPA: hence these bands may be attributed to the surface chemistry of the Macor. The $3340 \mathrm{~cm}^{-1}$ feature may reflect the dehydration of surface $\mathrm{OH}$ 
groups and the bands between 3600 and $3770 \mathrm{~cm}^{-1}$ changes in the nature and coverage of isolated O-H moieties ${ }^{34}$. The features at 2976, 2887, 1007 and $950 \mathrm{~cm}^{-1}$ are due to the loss of adsorbed IPA..$^{39,41,44,45,48,51,57}$ Of significance is the fact that there are no obvious product features.

\section{The plasma experiments}

The plasma experiments were carried out at 18, 20,22, 24, 26 and $27 \mathrm{~W}$ (the plasma became unstable at $28 \mathrm{~W}$ ). The various product features observed were the same in all the experiments.

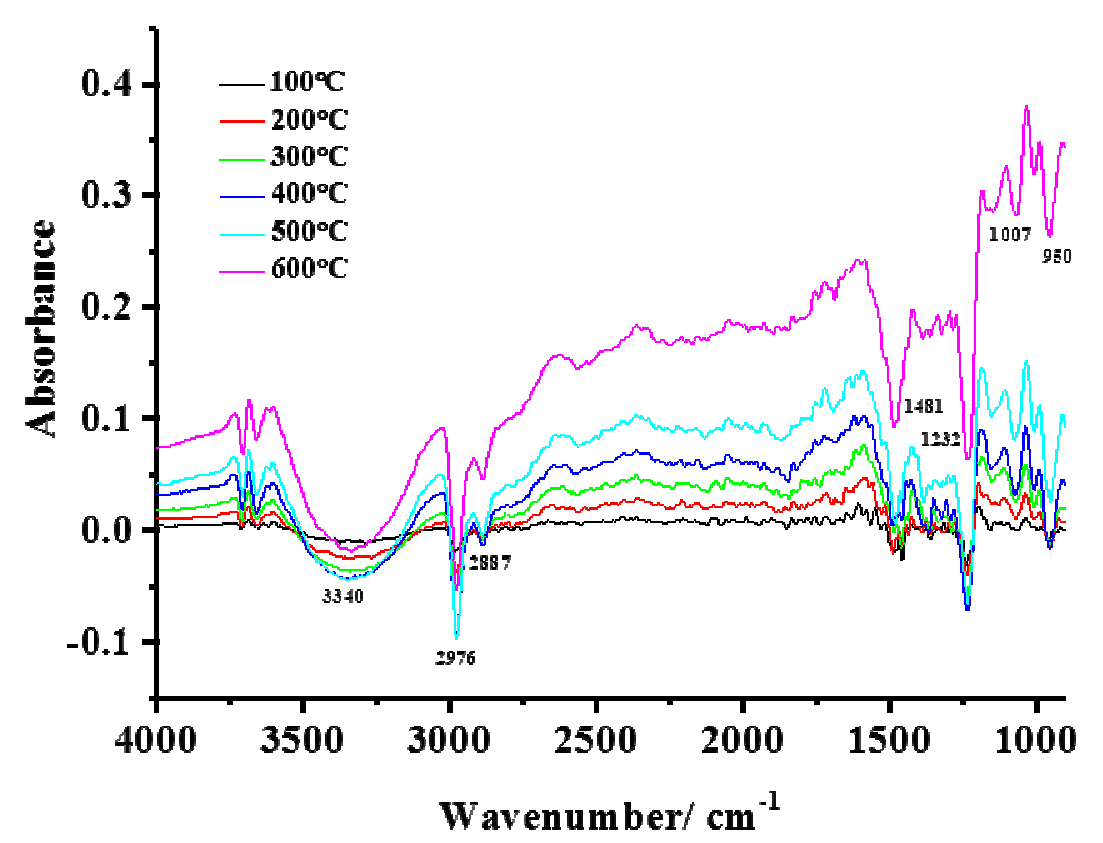

Figure 1. FTIR spectra (100 co-added scans and averaged scans at $4 \mathrm{~cm}^{-1}$ resolution, ca. 120 seconds per scan set) collected from a $12.5 \mathrm{~mm}$ diameter, $2 \mathrm{~mm}$ thick Macor disc in a static atmosphere of isopropyl alcohol vapour in nitrogen gas during an experiment in which the reference spectrum was taken at $25{ }^{\circ} \mathrm{C}$; the temperature was then ramped up at $5{ }^{\circ} \mathrm{C} \min ^{-1}$ and sample spectra collected every $50{ }^{\circ} \mathrm{C}$ from $50^{\circ} \mathrm{C}$ to $600{ }^{\circ} \mathrm{C}$. 


\section{The spectra collected at 1 minute}

\section{Spectral acquisition commenced 1 minute after initiating the plasma: this period was chosen} simply to allow some time for the system to settle, rather than assuming the plasma had reached steady state. Figure 2(a) shows the spectra collected after 1 minute during a series of experiments carried out as a function of input power (see the discussion around Figure S6 below), the reference spectra in each case being collected of the IPA-containing $\mathrm{N}_{2}$ gas without plasma. As expected, the figure is dominated by loss features due to gas phase IPA; see Figure S2, which compares spectra of liquid and gas phase IPA, and Table 2 which lists the various features. As can be seen from Figure S2, the 3657, the doublet at 1472 and 1462 and the distinctively-shaped band at $1251 \mathrm{~cm}^{-1}$ are characteristic of the gas phase IPA, whilst the cluster of bands at 1160,1130 and $1111 \mathrm{~cm}^{-1}$ and single, sharp feature at $952 \mathrm{~cm}^{-1}$ are characteristic of the liquid phase IPA. It is clear from Figure 2(a) that there is vibrational structure on the high frequency side of the IPA C-H loss features on all the spectra, as well as gain features below ca. $2250 \mathrm{~cm}^{-1}$; however, these are obscured by the strong loss features due to gas phase IPA. Hence, in order to highlight any small features, the gas phase IPA spectrum was subtracted from the spectrum collected at $27 \mathrm{~W}$ in Figure 2(a), using the $3657 \mathrm{~cm}^{-1} \mathrm{O}-\mathrm{H}$ feature in the gas phase spectrum to determine the scaling factor to ensure annulling of the IPA bands; the result is shown in Figure 2(b) and the various features so observed summarized in Table 3.

The gain features at $3335 \mathrm{~cm}^{-1}$ and $3284 \mathrm{~cm}^{-1}$ may be attributed to the $\mathrm{P}$ and $\mathrm{R}$ branches of $\mathrm{HCN}:{ }^{56}$ these features were present on all the spectra collected after 1 minute operation. The fine structure centred on $3086 \mathrm{~cm}^{-1}$ and the sharp band at $3016 \mathrm{~cm}^{-1}$ in Figure 2(a) may be unambiguously attributed to the $\mathrm{P}$ and $\mathrm{Q}$ branches of the $v_{3}$ band of $\mathrm{CH}_{4}$, and the sharp feature at 
Table 2. The IR absorptions of gas and liquid phase isopropyl alcohol. ${ }^{39-42,45,48,51,57}$

\begin{tabular}{|c|c|c|}
\hline $\begin{array}{l}\text { Gas phase } \\
\text { IPA } / \mathrm{cm}^{-1}\end{array}$ & $\begin{array}{l}\text { Liquid phase } \\
\text { IPA } / \mathrm{cm}^{-1}\end{array}$ & Assignment \\
\hline 3657 & 3347 & $v_{\mathrm{OH}}$ \\
\hline 2980 & & $v_{\mathrm{aCH} 3}$ \\
\hline 2971 & 2971 & $v_{\mathrm{aCH} 3}$ \\
\hline 2933 & 2932 & $v_{\mathrm{sCH} 3}$ \\
\hline \multicolumn{3}{|l|}{$2900(\mathrm{sh})$} \\
\hline 2886 & 2883 & $v_{\mathrm{CH}}$ \\
\hline 1472 & 1466 & $\delta_{\mathrm{aCH} 3}$ \\
\hline \multirow[t]{2}{*}{1462} & & $\delta_{\mathrm{aCH} 3}$ \\
\hline & 1408 & \\
\hline \multirow[t]{3}{*}{1383} & 1379 & $\delta_{\mathrm{sCH} 3}$ \\
\hline & 1340 & \\
\hline & 1310 & \\
\hline 1251 & & $\delta_{\mathrm{OH},} \delta_{\mathrm{CH}}$ \\
\hline \multirow[t]{3}{*}{1152} & 1160 & $v_{\mathrm{CC}}, v_{\mathrm{CO}}, \mathrm{r}_{\mathrm{CH} 3}$ \\
\hline & 1130 & \\
\hline & 1111 & \\
\hline $1080(\mathrm{sh})$ & & $v_{\mathrm{CC}}, \mathrm{r}_{\mathrm{CH} 3}$ \\
\hline 1073 & & $v_{\mathrm{CC}}, \mathrm{r}_{\mathrm{CH} 3}$ \\
\hline 966 & & $\begin{array}{l}\text { Terminal and bridged } \mathrm{C}-\mathrm{O} \\
\text { str. }\end{array}$ \\
\hline 954 & 952 & \\
\hline 942(sh) & & \\
\hline
\end{tabular}


Table 3. The features in Figure 2(b). See text for details.

\begin{tabular}{|l|l|}
\hline$/ \mathrm{cm}^{-1}$ & Assignment \\
\hline $3335+3284$ & $\mathrm{HCN}$ \\
\hline $2732+2705$ & $?$ \\
\hline $2164+2130$ & "Cold" CO \\
\hline 1666 & Isophorone \\
\hline 1740 & Acetone \\
\hline 1369 & Acetone \\
\hline 1215 & Acetone \\
\hline $3086+3016$ & P and Q bands of $v_{3}$ band of $\mathrm{CH}_{4}$ \\
\hline 1305 & Q branch of $v_{4}$ band of $\mathrm{CH}_{4}$ \\
\hline
\end{tabular}

$1305 \mathrm{~cm}^{-1}$ to the $v_{4}$ band of $\mathrm{CH}_{4}{ }^{58}$ by comparison with an authentic sample of $\mathrm{CH}_{4}$ in $13.4 \%$ $\mathrm{CH}_{4}+10.6 \% \mathrm{CO}_{2}+76.0 \% \mathrm{~N}_{2}$, see Figure S3, the Q branch in Figure 2(b) is distorted by the IPA C-H loss feature.

The bands at $1740 \mathrm{~cm}^{-1}, 1369$ and $1215 \mathrm{~cm}^{-1}$ may be attributed to gas phase acetone ${ }^{59}$ an assignment confirmed by comparison with the IR spectrum of an authentic sample. Thus, Figures S4(a) and (b) show the spectrum in Figure 2(b) and a spectrum of gas phase acetone obtained by placing ca. $0.1 \mathrm{~cm}^{3}$ of the liquid in the plasma transmission cell and allowing it to evaporate. As well as the $\mathrm{C}=\mathrm{O}$ band at $1740 \mathrm{~cm}^{-1}$ and the band at $1369 \mathrm{~cm}^{-1}$ the features at 1130 , 1217 and $1228 \mathrm{~cm}^{-1}$ form a highly distinctive group which may be unambiguously assigned to acetone. It is clear from Figures $\mathrm{S} 4(\mathrm{a})$ and (b) that the broad feature around $3347 \mathrm{~cm}^{-1}$, the features at 2968 and $2978 \mathrm{~cm}^{-1}$, the multiple bands around $1130 \mathrm{~cm}^{-1}$ and the feature at $1046 \mathrm{~cm}^{-1}$ 
are not due to acetone. With the exception of the $1046 \mathrm{~cm}^{-1}$ feature which remains unassigned, these bands may be attributed to liquid IPA condensing on the cell windows, and this is discussed in detail below as is the origin of the broad feature at ca. $1666 \mathrm{~cm}^{-1}$.

There are at least two possible routes to acetone: the dehydrogenation of IPA over metal and metal oxide catalysts is a well-known endothermic ${ }^{60}$ and important reaction requiring temperatures $\geq 200{ }^{\circ} \mathrm{C}$ catalysed by basic oxides including $\mathrm{MgO}{ }^{60-63}$; hence it may be that the acetone is produced in an analogous process involving the removal of dihydrogen from the $\mathrm{H}$ of the hydroxyl group and an $\mathrm{H}$ atom on the carbon adjacent to the $\mathrm{CHOH}$ moiety. However, such a surface process would be inhibited by the formation of the liquid film, and the data below suggest that the formation of acetone is linked to that of $\mathrm{CO}$ and $\mathrm{HCN}$, hence it is more likely that the acetone is produced from an entirely gas-phase process; for example, from mass spectrometry studies of IPA, acetone can be produced by deprotonation of $\mathrm{C}_{3} \mathrm{H}_{7} \mathrm{O}^{+}{ }^{64}$

It does not seem unreasonable to assign the bands at 2164 and $2130 \mathrm{~cm}^{-1}$ to the $\mathrm{P}$ and $\mathrm{R}$ branches of a linear molecule. In addition, the reasonably high frequency of the band centre suggests a light molecule; further the band centre is identical to that of gas phase CO $\left(2145 \mathrm{~cm}^{-}\right.$ ${ }^{1}$ ), see Figure S5 which shows the features in Figure 2(b) compared to an authentic sample of CO. The 2164 and $2130 \mathrm{~cm}^{-1}$ bands resemble the $\mathrm{P}$ and $\mathrm{R}$ branches of $\mathrm{CO}$, except with a reduced bandwidth, as would be expected if the molecule was cooled down: for example, Bauerecker et al. ${ }^{65}$ observed the rotation-vibration bandwidth of ${ }^{13} \mathrm{C}^{16} \mathrm{O}$ to be reduced by about $40 \%$ on cooling the gas from $300 \mathrm{~K}$ to $45 \mathrm{~K}$, without any change in band centre. From Figure $\mathrm{S} 5$, the bandwidth is ca. $24 \%$ lower than that of CO at room temperature, and a calculation based 
on separation of the maxima of the $\mathrm{P}$ and $\mathrm{R}$ branches ${ }^{66}$ suggest a temperature of ca. $115 \mathrm{~K}$, in broad agreement with the work of Bauerecker and co-workers; if the resolution is taken into account, this gives a temperature range of $89-143 \mathrm{~K}$. This is a challenging observation as it would be expected that the gas phase molecules in the plasma glow would be in thermal equilibrium: however, it may simply be the case that the cold $\mathrm{CO}$ bands represent the steady state of the species, constantly produced and constantly removed by the gas feed.

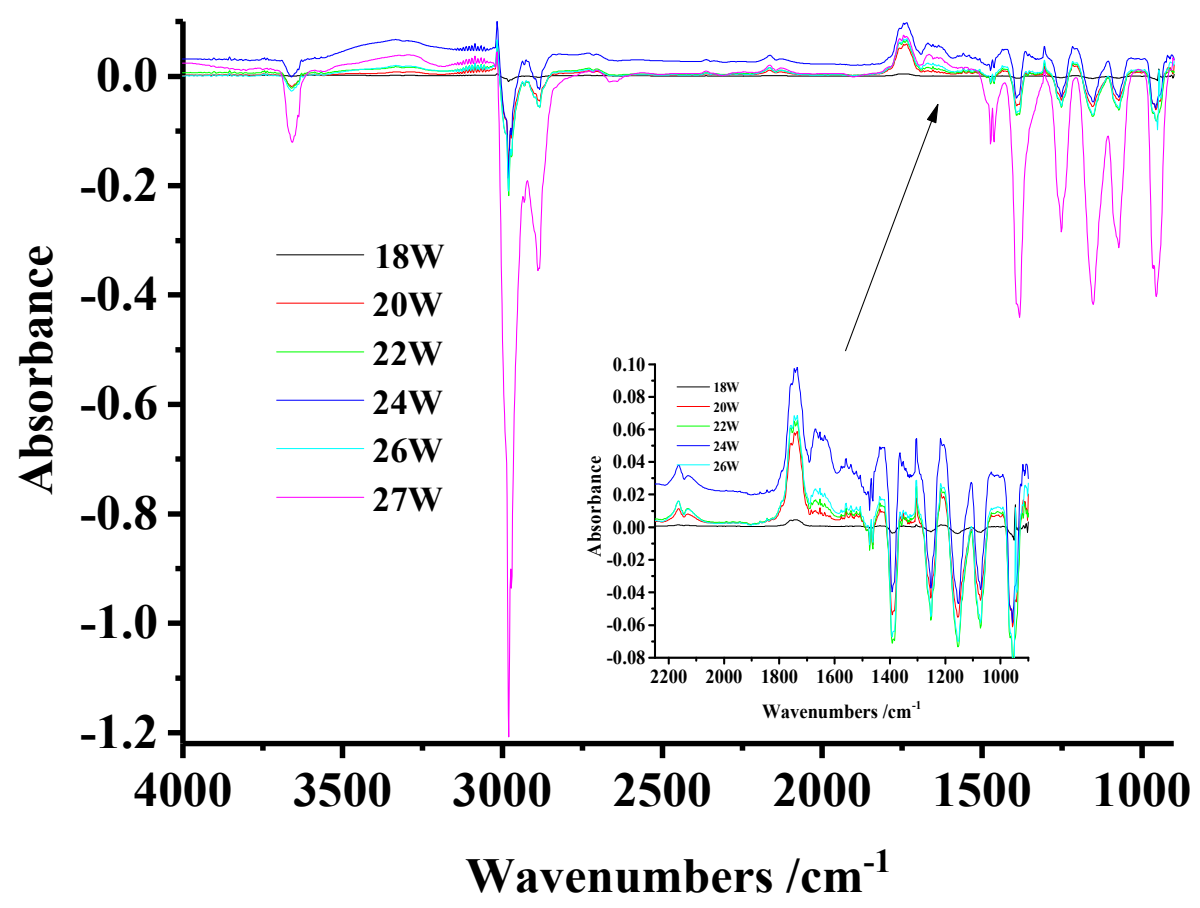

(a) 


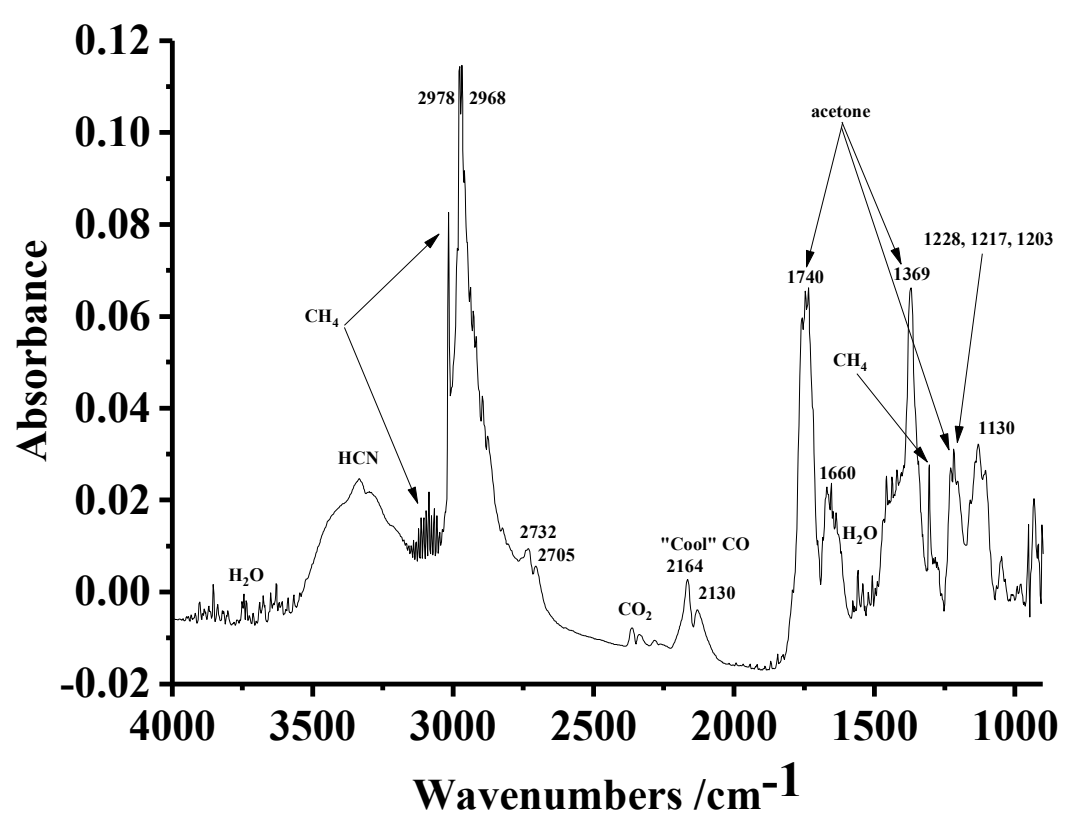

(b)

Figure 2. (a) FTIR spectra (100 co-added scans and averaged scans at $4 \mathrm{~cm}^{-1}$ resolution, ca. 100 seconds per scan set) collected during experiments in which nitrogen gas was passed through isopropyl alcohol at $298 \mathrm{~K}$ and atmospheric pressure into the IR plasma transmission cell at a flow rate of $200 \mathrm{~cm}^{3} \mathrm{~min}^{-1}$ and a reference spectrum collected. The plasma was then initiated sample spectra collected as a function of time. The spectra shown were collected after 1 minute at the various input powers shown. The inset shows the spectra below $2200 \mathrm{~cm}^{-1}$ without the spectrum taken at $27 \mathrm{~W}$, for clarity. (b) The spectrum collected at an input power of $27 \mathrm{~W}$ in Figure 2(a).

Figure S6 shows typical spectra collected at an input power of $27 \mathrm{~W}$ using the spectrum collected without plasma as reference: as can be seen, the $\mathrm{CH}_{4}$ and $\mathrm{CO}$ bands (boxed) are present, and their intensities unchanged throughout the experiment indicating steady-state 
concentrations: this postulate was supported by the IPA/Ar data discussed below. The HCN features also do not change in intensity with time and hence were annulled when the spectrum collected at 1 minute was subtracted from those collected at longer times, (see Figure 4) and discussion below. It did not prove possible to determine the behaviour of the acetone due to the overlying strong features.

Figure 3 shows plots of the partial pressure of methane, and the absorbances of the $\mathrm{CO}$ band at $2164 \mathrm{~cm}^{-1}$ and the $1740 \mathrm{~cm}^{-1}$ acetone band normalised to their maximum values, as a function of input power, measured from the spectra collected after 1 minute and using the spectra collected without plasma as the background. The raw data are presented in Figure S7. As can be seen, all three species apparently track each other, suggesting they are formed via a common intermediate and/or in the same process, and this postulate was supported by the experiment discussed below in which $\mathrm{N}_{2}$ was replaced by Ar.

In the plasma transmission cell, the IR beam passed along the surfaces of both the Macor caps, but bands attributable to adsorbed IPA were not observed in any of the spectra recorded using the cell.

\section{The spectra collected at longer times}

Figure 4 shows the spectrum collected after 1 minute in Figures 2(a) and S6 subtracted from those taken at longer times in order to remove the loss features due to gas phase IPA; as may be 


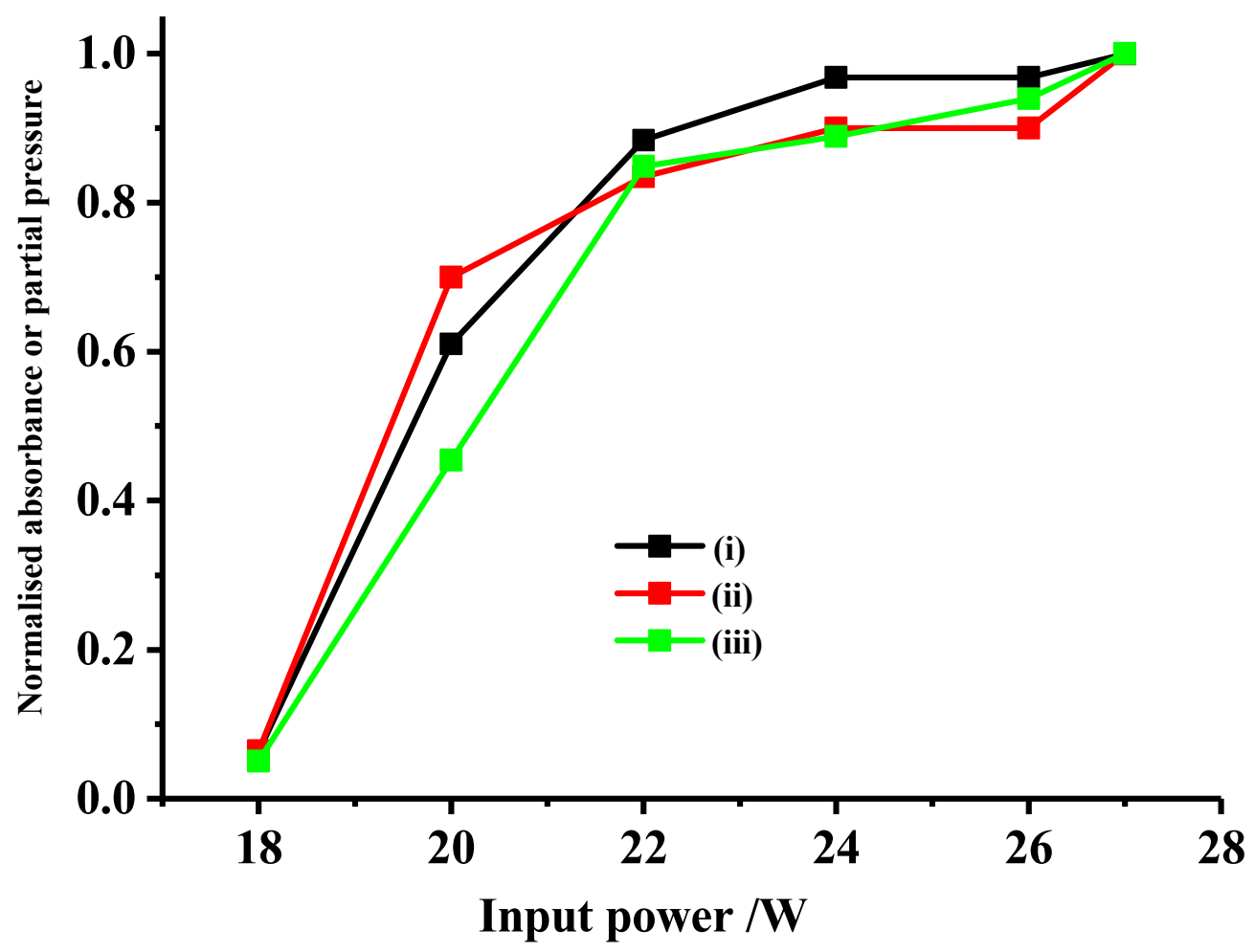

Figure 3. Plots of (i) the absorbance of the $2164 \mathrm{~cm}^{-1} \mathrm{CO}$ band, (ii) the partial pressure of $\mathrm{CH}_{4}$ and (iii) the absorbance of the $1740 \mathrm{~cm}^{-1}$ acetone band, measured after 1 minute plasma operation as a function of input power from the experiments shown in Figure 2(a). The plots were normalised to their maximum values.

seen from the figure, there is no further reduction in the vapour pressure of the IPA as a function of time once the power to the plasma is switched on. Following the experiment depicted in the figure, a brown oily deposit was observed on the Macor plates and $\mathrm{CaF}_{2}$ windows, which was also observed in all the plasma experiments using IPA and nitrogen, and the IR spectrum of which corresponded closely to the spectrum collected after 20 minutes in Figure 4 . As will be discussed further below, this oil appeared to comprise at least two components, A and B. The oil 
was dissolved in $\mathrm{CdCl}_{3}$ and an attempt was made to analyse it with carbon and proton NMR, but the results were inconclusive

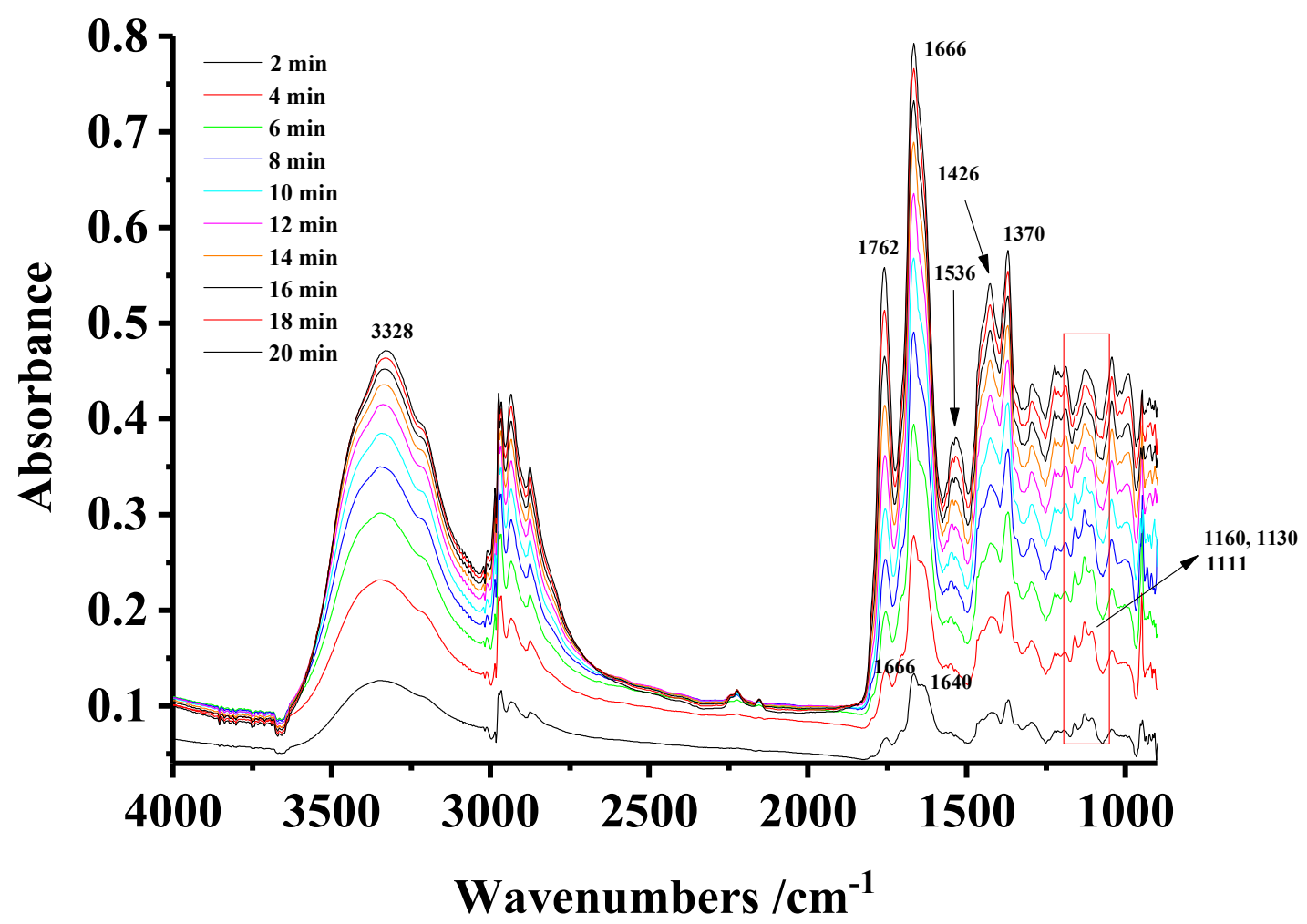

Figure 4. The spectra obtained during the experiment carried out at 27W shown in Figure 2(a). The spectra were collected using a gas feed of IPA vapour in $\mathrm{N}_{2}$. The $\mathrm{N}_{2}$ was bubbled through pure IPA at $298 \mathrm{~K}$ at a flow rate of $200 \mathrm{~cm}^{3} \mathrm{~min}^{-1}$. The reference spectrum was collected under the same conditions, but without plasma. The spectrum collected after 1 minute was subtracted from those taken up to 20 minutes.

Figure 5 shows plots of the key features in Figure 4 as a function of time normalized to their maximum values, and Figure S8 shows the raw data. As can be seen from Figures 4 and 5, the 1762 and $1536 \mathrm{~cm}^{-1}$ bands track each other and may thus be assigned to a single species; it is 
also clear that the 1666,1426 and $1370 \mathrm{~cm}^{-1}$ features do not belong to the same species as the 1762 and $1536 \mathrm{~cm}^{-1}$ bands. Unfortunately, the 1426 and $1370 \mathrm{~cm}^{-1}$ bands are in the spectral region where significant overlap of bands from different species may be expected. This challenge is addressed further below.

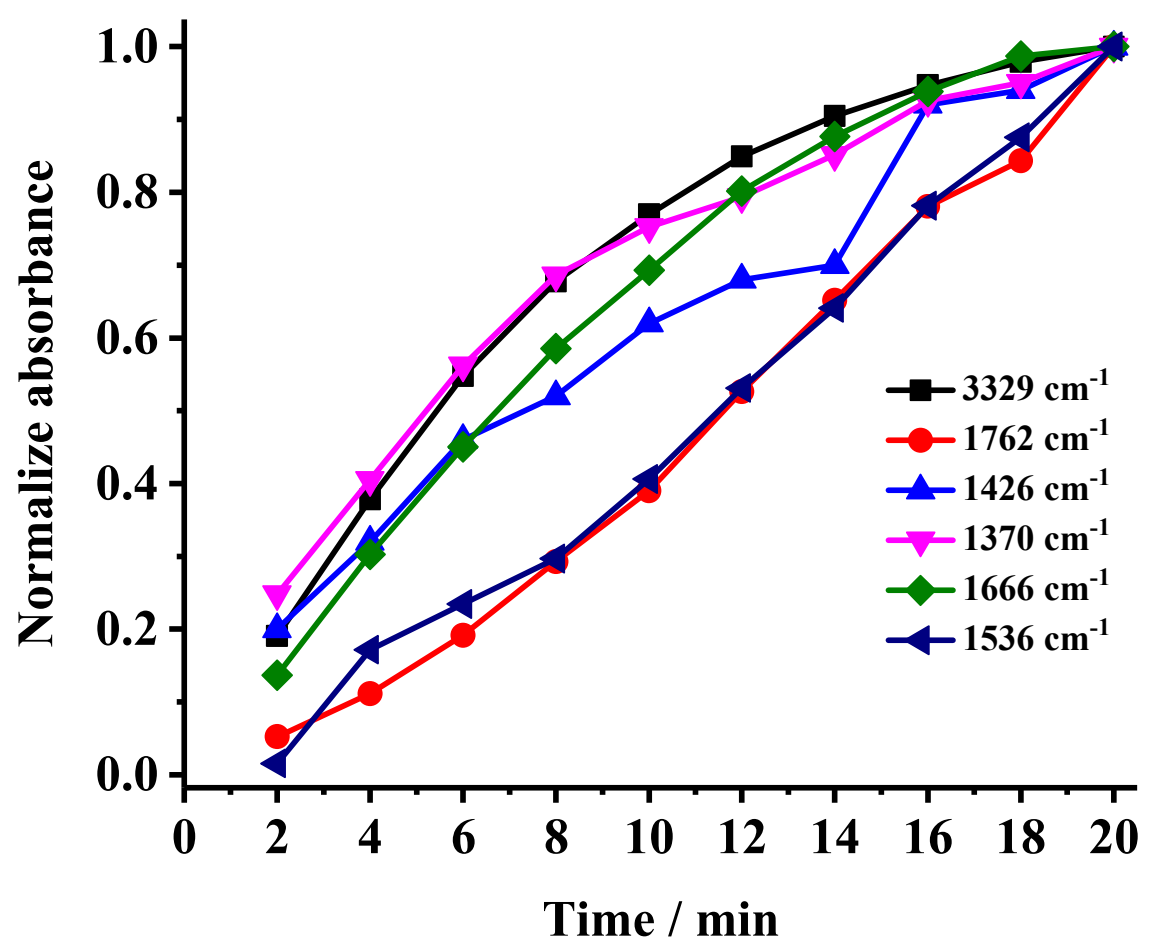

Figure 5. Plots of the intensities of the key features in Figure 4 as a function of time, normalized to their maximum values.

Close inspection of Figure 4 shows the distinctive 1160, 1130 and $1111 \mathrm{~cm}^{-1}$ bands attributable to liquid phase IPA, suggesting condensation on the windows and surfaces of the cell, which become indistinct in the spectra collected after 8 minutes. These bands do not appear to change in intensity significantly up to 8 minutes, suggesting the thickness of the condensed layer does not change over this timescale. These observations suggest that the spectra in Figure 4 could be 
simplified if divided into two regions, those up to $8 \mathrm{~min}$ from which was subtracted the spectrum collected after 1 minute, and the spectrum taken at 8 minutes subtracted from those taken up to 20 minutes. The results are shown in Figures S9 and S10.

By comparing the relative intensities of the various features in Figures S9 and S10 it is clear that there are bands due to at least two different species, some isolated as discussed above, but some clearly overlapping in the spectral region below $1500 \mathrm{~cm}^{-1}$. Figure 6 shows the spectra collected at 8 minutes in Figure S9 and that at 20 minutes in Figure S10 along with the spectrum of liquid IPA in Figure S2 scaled such that the $1130 \mathrm{~cm}^{-1}$ feature is approximately the same intensity as that in Figure S9. It is clear that the peak at $2970 \mathrm{~cm}^{-1}$ in Figures 6 and S9 is due to liquid IPA, that there is a significant contribution from liquid IPA to the broad feature between 2500 and $3700 \mathrm{~cm}^{-1}$ in the spectra collected up to 8 minutes and that there are features below $1500 \mathrm{~cm}^{-1}$ belonging to both the unidentified species characterized by the strong bands at 1762 and $1666 \mathrm{~cm}^{-1}$. The situation becomes clearer if the spectra collected at $10 \mathrm{~min}$ and $20 \mathrm{~min}$ in Figure S10 are compared, see Figure 7; thus the 1762, 1536, 1426 and 1370 belong to one species, species A, and the $1666,1630(\mathrm{sh}), 1430,1385$ and $1373 \mathrm{~cm}^{-1}$ features to species B. It is not clear from the various figures what species is responsible for the $3329 \mathrm{~cm}^{-1}$ absorption: thus from Figure 6 it can be seen that there is an appreciable contribution from the $\mathrm{O}-\mathrm{H}$ stretch of liquid IPA to the O-H absorption up to 8 minutes, and there are marked differences in the shape of the feature between the two NTP spectra in the figure. Further, it appears from Figure 6 that the 2936 and $2876 \mathrm{~cm}^{-1} \mathrm{C}-\mathrm{H}$ bands are common to both species A and B, if in different relative intensities. The various features are summarised in Table 4. The time-dependent behaviour of 
the intensities of the 1426 and $1370 \mathrm{~cm}^{-1}$ species A bands in Figure 5 is clearly distorted by the presence of the underlying 1430,1385 and $1373 \mathrm{~cm}^{-1}$ features of species B.

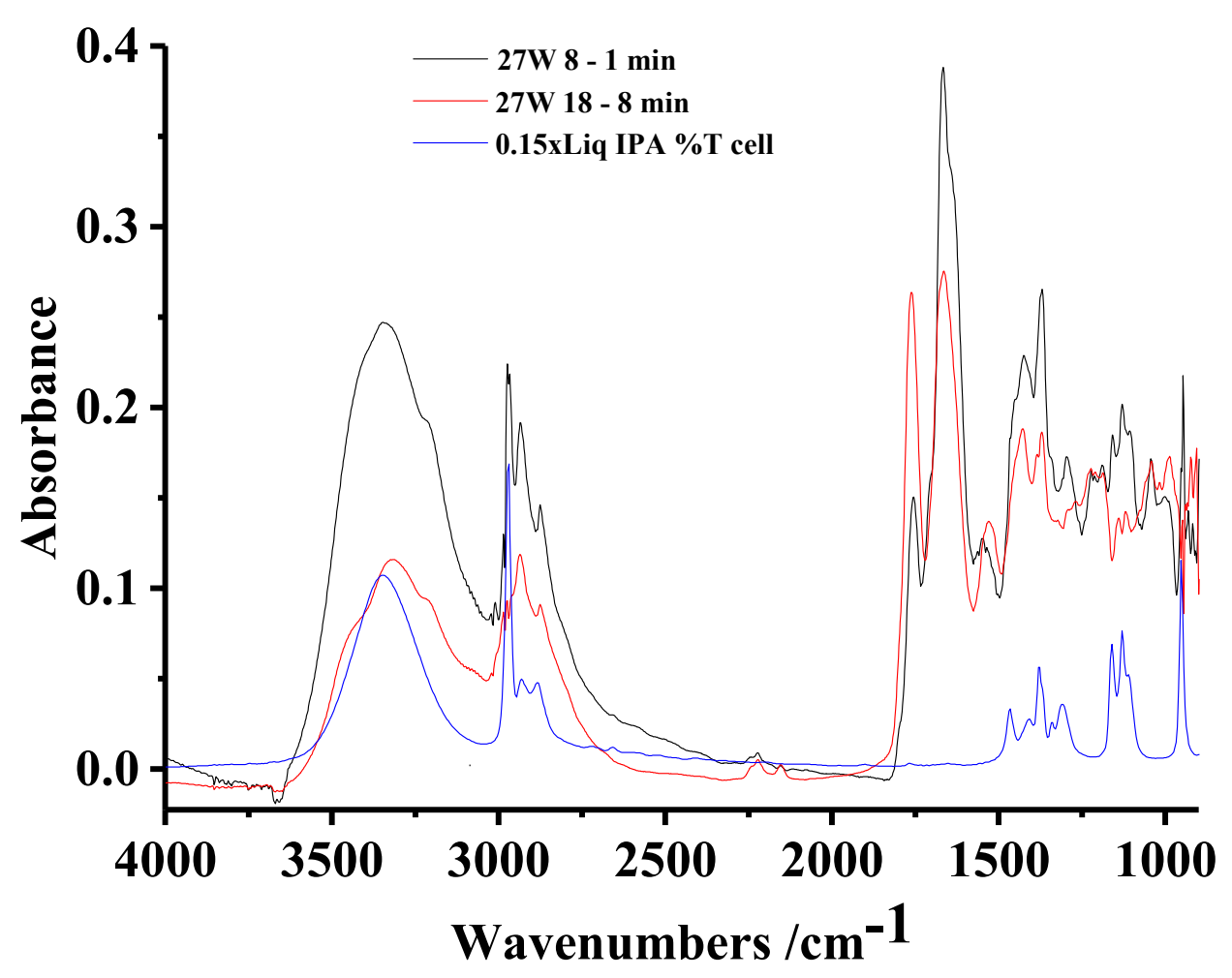

Figure 6. A comparison of the spectrum (i) collected after 8 minutes in Figure S9, (ii) the spectrum taken after 20 minutes in Figures S10, and (iii) the spectrum of liquid IPA in Figure S2. See text for details. 


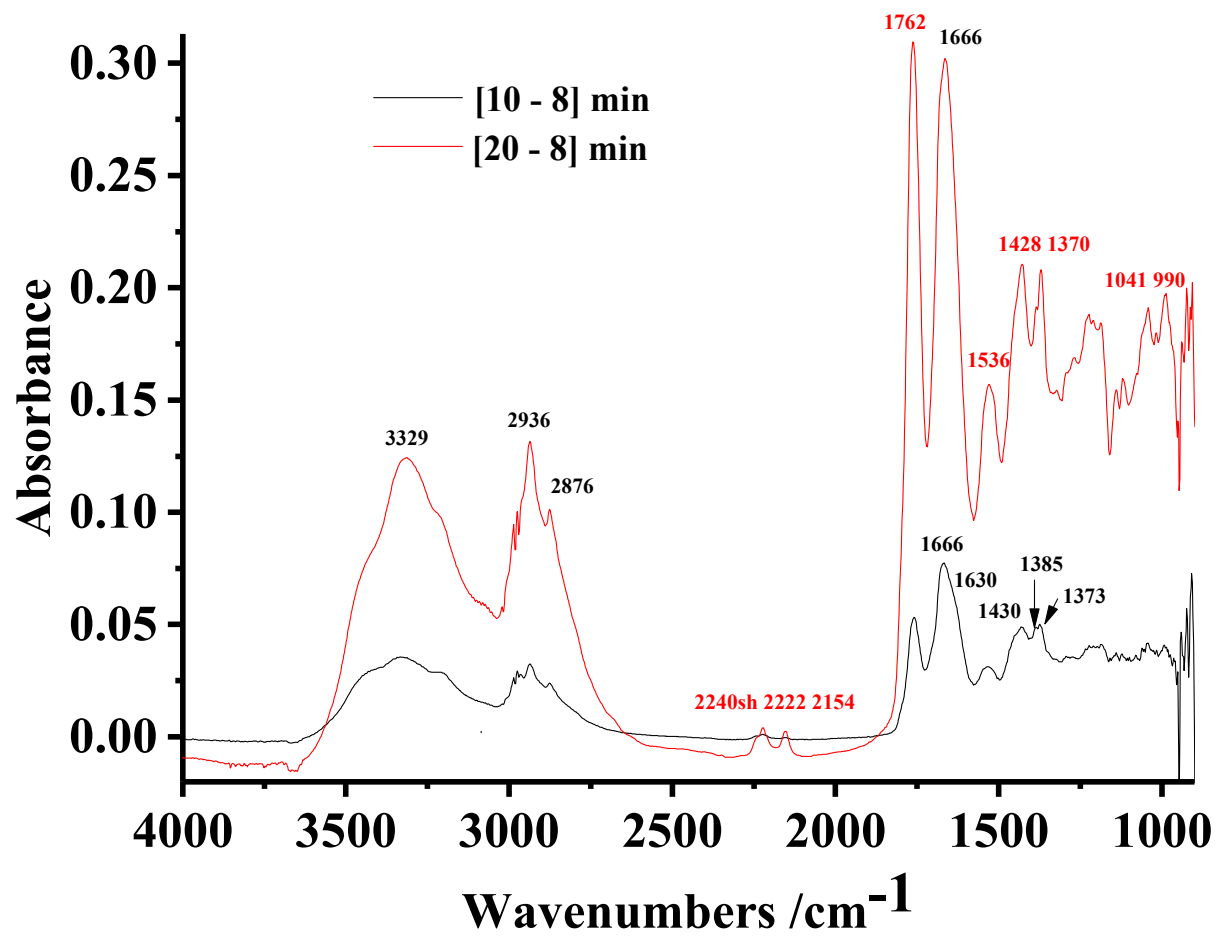

Figure 7. The spectra collected after (i) 10 minutes and (i) 20 minutes in Figure S10. See text for details.

The acetone generated from the IPA may undergo a range of transformations leading to higher molecular species bearing both $\mathrm{C}=\mathrm{O}$ and $-\mathrm{OH}$ groups such as $\beta$-hydroxyketones (acid and/or base catalysed Aldol reaction) and diols resulting from $\mathrm{Mg}$ catalysed Pinacol coupling. The nature and distribution of the products is dependent upon the catalyst employed as is the extent of similar downstream reactions with additional structural complexity due to facile dehydration of these materials installing random elements of unsaturation. This sequence of events inevitably produces an orange or red polymeric oil ${ }^{67,68}$ containing $\mathrm{CH}_{3}, \mathrm{C}=\mathrm{O}, \mathrm{C}=\mathrm{C}$ and $\mathrm{O}-\mathrm{H}$ groups. The number, distribution and nature of these functionalities are a result of both the catalyst and the experimental conditions employed, and the polymers produced are described generically as 
"polymethylacetylene-like". The C-H asymmetric and symmetric stretches are observed at ca. 2960 and $2865 \mathrm{~cm}^{-1}$, respectively, and the absorptions due to $\mathrm{C}=\mathrm{O}$ conjugated with the polyene structure appear around 1705 and $1670 \mathrm{~cm}^{-1}$, the latter much stronger than the former. The $\mathrm{C}=\mathrm{C}$ stretch of the polyene backbone moves down in frequency as the conjugation increases, se $^{69}$ and references therein, and was reported to absorb around $1560 \mathrm{~cm}^{-1}$ in the seminal work by Cataldo. ${ }^{67,68}$ If the conjugation between the ketone $\mathrm{C}=\mathrm{O}$ moieties and the polyene backbone is broken, often by cyclisation and/or the formation of quaternary carbon centres (e.g. geminal $\mathrm{CMe}_{2}$ groups), the polyene $\mathrm{C}=\mathrm{C}$ absorption does not shift, but the $\mathrm{C}=\mathrm{O}$ absorption moves to significantly higher frequencies. The fact that $\mathrm{N}_{2}$ (along with Macor and IPA) is essential to the formation of the liquid film suggests that nitrogen-containing moieties are also present in the polymer. Thus we suggest that species A is a polymeric product resulting from a cascade of Aldol/Pinacol/dehydration type reactions initiated by the formation of acetone. Trinh and Mok ${ }^{70}$ investigated the oxidative decomposition of acetone over $\mathrm{ZnO}$ and/or $\mathrm{MnO}_{2}$ catalysts and observed the formation of a brown polymeric deposit on the walls of their reactor. The IR spectrum of this deposit shows similarities to the spectra in Figure 4, and the authors postulated the polymer contained ester groups.

In the thermally-driven Aldol condensation of acetone over alkaline catalysts, as well as polymethylacetylene-like products, isophorone is a common side product (e.g. from cyclisation and subsequent $\mathrm{E}_{1 \mathrm{CB}}$ elimination of water). Figure $\mathrm{S} 11$ shows the spectrum of an authentic sample of isophorone, and the absorptions are summarized in Table 4. On the basis of the spectrum, we identify product B as isophorone. Interestingly, isophorone is one of the products 
Table 4. The features observed in the spectra in Figures 4 and S6, S9 \& S10, and the absorptions of isophorone from Figure S11.

\begin{tabular}{|l|l|l|}
\hline $\begin{array}{l}\text { Product A } \\
\text { bands } / \mathrm{cm}^{-1}\end{array}$ & $\begin{array}{l}\text { Product B } \\
\text { bands } / \mathrm{cm}^{-1}\end{array}$ & $\begin{array}{l}\text { Isophorone } \\
/ \mathrm{cm}^{-1}\end{array}$ \\
\hline 2936 & 2936 & 2957 \\
\hline 2876 & 2876 & 2869 \\
\hline 1762 & 1666 & 1668 \\
\hline 1536 & $1630(\mathrm{sh})$ & 1630 \\
\hline 1426 & 1430 & 1435 \\
\hline 1370 & 1385 & 1378 \\
\hline & 1373 & 1367 \\
\hline
\end{tabular}

from the thermal Aldol condensation of acetone at lamellar double hydroxides which, as is the case with Macor, also contain magnesium and aluminium oxides. ${ }^{71}$

Close inspection of the spectrum collected after 2 minutes in Figure 4 shows that the $\mathrm{OH}$ band is prominent, as is a clear band at $1640 \mathrm{~cm}^{-1}$. The latter does not track the adjacent $1666 \mathrm{~cm}^{-1}$ and becomes overlain by the $1630 \mathrm{~cm}^{-1}$ shoulder. The presence of the $1640 \mathrm{~cm}^{-1}$ and the broad O-H absorption, along with the sloping absorption that increases at frequencies $>1750 \mathrm{~cm}^{-1}$ and the clear, broad absorption underlying the bands below $1750 \mathrm{~cm}^{-1}$ suggest the formation of water $^{72}$, along with $\mathrm{C}-\mathrm{OH}$ groups: the former arising from the Aldol condensation reaction.

The production of the gas phase products $\mathrm{CO}, \mathrm{CH}_{4}$ and $\mathrm{HCN}$, and the fact that they fairly rapidly attain a steady-state in the plasma in the flowing feed gas, in conjunction with the 
separate production of the isophorone and the polymer-containing brown oil, which requires a longer time to form, suggests the presence of two separate and parallel reaction pathways. This observation is in accord with the model of Kim et al. ${ }^{73}$ in which the active species such as $\mathrm{OH}$ radicals occupy a thin layer perhaps $50 \mu \mathrm{m}$ thick above the catalyst and are available for reaction at the catalyst: above this layer, species produced in the plasma react in the same way as in the absence of catalyst. Thus the gas phase products are produced in the body of the plasma, away from the direct participation of the catalyst, whilst the isophorone and polymer are produced in the plasma adjacent to the catalyst: both possibly require the build-up of intermediates on the Macor, but, as may be seen from the plots in Figure 5, the isophorone is produced in a different process to the polymer, and more rapidly.

\section{Replacing nitrogen with argon}

Figure 8(a) shows the spectra obtained in an analogous experiment to that in Figure 4 except that the nitrogen feed was replaced by argon. The plasma was initiated at a significantly lower power ( $8 \mathrm{~W}$ in contrast to $18 \mathrm{~W}$ using $\mathrm{N}_{2}$ ) and the spectra in Figure $8($ a) were collected at $8 \mathrm{~W}$. The most obvious difference between the two experiments, apart from the expected absence of HCN in Figure 8(a), was that no liquid film or isophorone was produced, clearly highlighting the importance of nitrogen gas in their formation. Cold $\mathrm{CO}$, at $136 \mathrm{~K}$ (allowing for the resolution gives a temperature range of $108-167 \mathrm{~K}$ ) was also produced. Figure $8(\mathrm{~b})$ shows the spectrum collected after 1 minute in Figure 8(a) with the IPA bands annulled by subtraction, using the O-H stretch at $3657 \mathrm{~cm}^{-1}$ to determine the scaling factor. The acetone bands are clear, as are the $\mathrm{CO}_{2}$, cold $\mathrm{CO}$ and methane absorptions. 
In addition to the bands stated above, there are features at 3315 and $3263 \mathrm{~cm}^{-1}$ in Figures 8 (a) and (b) which may be attributed to the C-H stretch of acetylene. ${ }^{74}$ Along with the inhibition of the film formation, the production of acetylene strongly suggests the existence of a modified mechanism on employing argon.

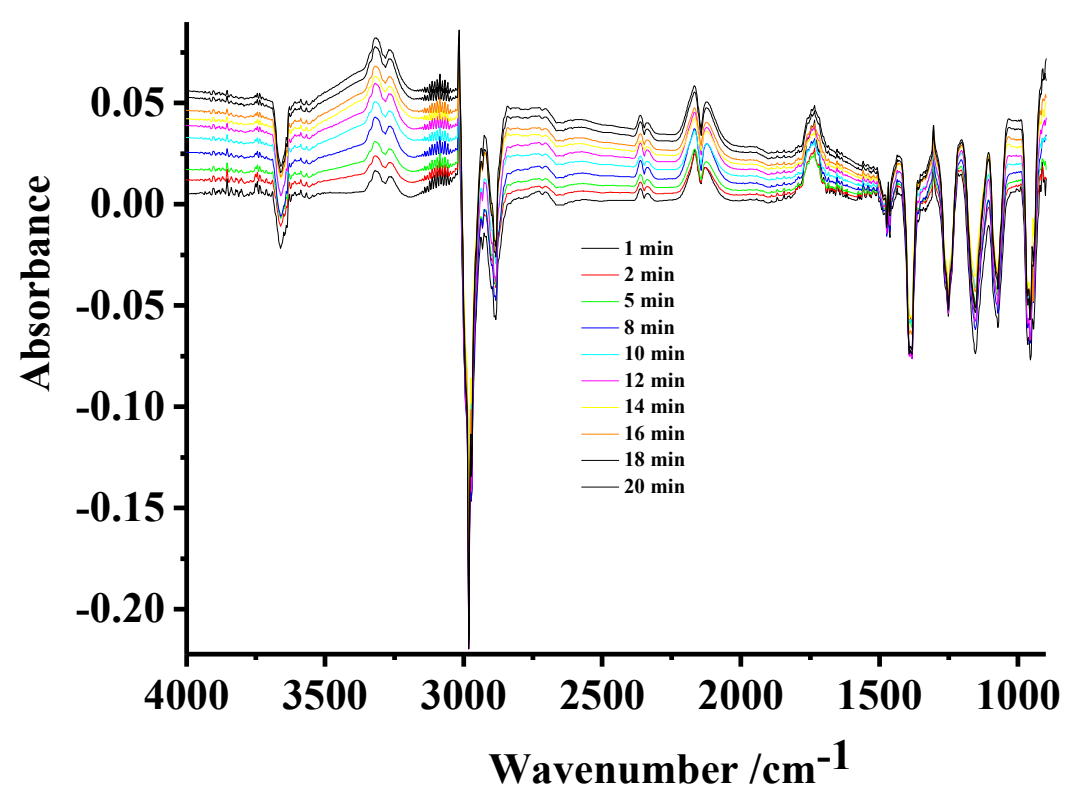

(a)

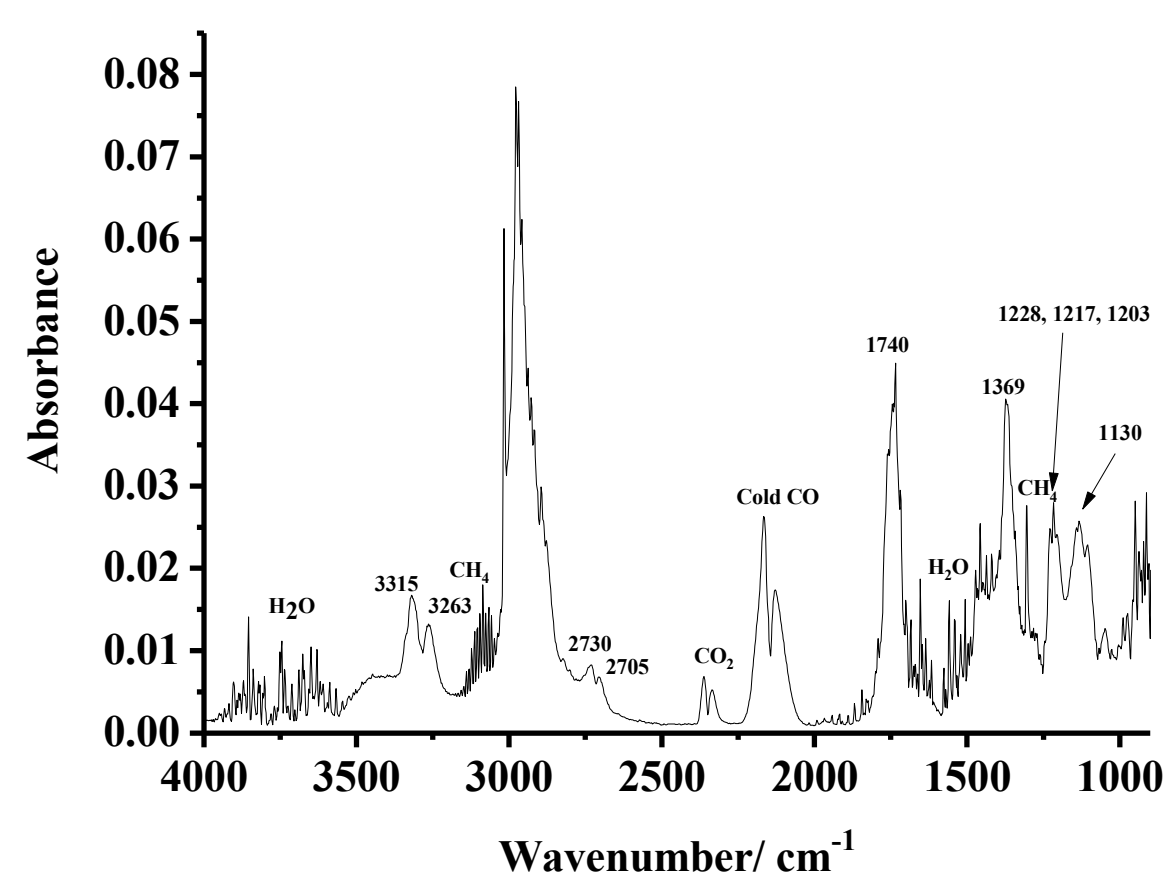

(b) 
Figure 8. (a) The spectra collected in an analogous experiment to that in Figure 4, except that the feed gas was argon and the input power $8 \mathrm{~W}$. (b) The spectrum collected after 1 minute in Figure 8(a). The gas phase IPA bands were annulled using the spectrum of pure IPA, and employing the $\mathrm{O}-\mathrm{H}$ stretch of the IPA at $3657 \mathrm{~cm}^{-1}$ to determine the subtraction factor.

Figure 9 shows plots of the various features in Figure 8(a) as a function of time. As was stated above, it is clear that (1) the methane, cold $\mathrm{CO}, \mathrm{CO}_{2}$ and acetone essentially show steady state concentrations (as was noted above), whereas the acetylene in the plasma glow steadily increases, and (2) with the exception of the acetylene the remaining species clearly track each other, suggesting they arise from the same or linked process(es). From the figure, the steady state partial pressure of methane was ca. $12 \mathrm{mBar}$, i.e. not insignificant. The oscillating nature of the plots in Figure 9 are fascinating, but their interpretation requires further study.

\section{The proposed mechanism}

First it will be useful to review the key facts arising from the data discussed above:

- It is clear that cold $\mathrm{CO}, \mathrm{CH}_{4}, \mathrm{HCN}$ and acetone are produced in the plasma glow in the first minute.

- From Figure $\mathrm{S} 6$ and numerous repeats, it is clear that $\mathrm{CH}_{4}$ and cold $\mathrm{CO}$ (at least) are produced for the full 20 minutes i.e. the formation of the liquid has no effect therefore their formation must take place entirely in the gas phase. 


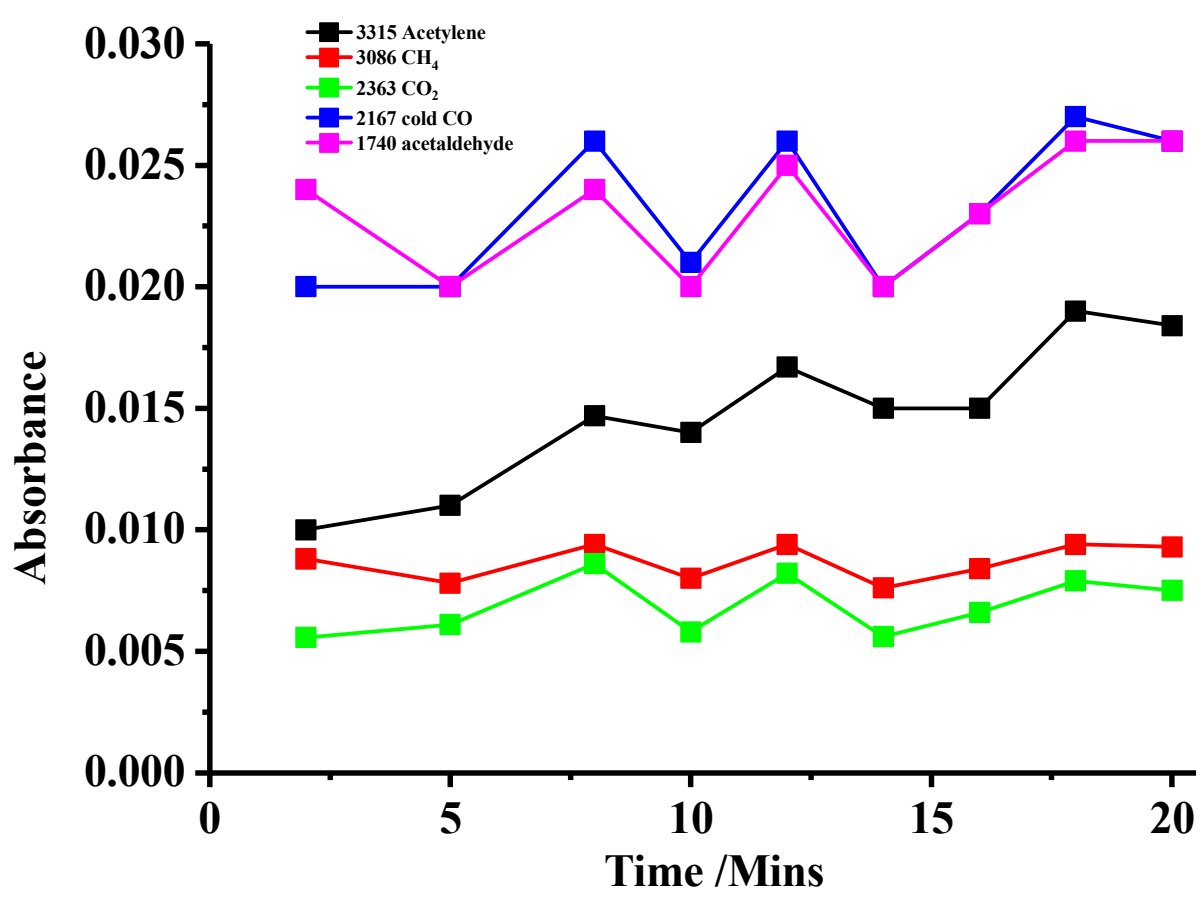

Figure 9. Plots of the intensities of the various features in Figure 8(a) as a function of time.

- It is clear from Figures 3 and 9 that $\mathrm{CO}, \mathrm{CH}_{4}, \mathrm{HCN}$ and acetone track each other exactly suggesting some commonality.

- Replacing $\mathrm{N}_{2}$ by Ar not only removes $\mathrm{HCN}$ but results in the formation of acetylene.

The production of cold CO suggests the presence of a "loose" or "late" transition state and hence the possible presence of a roaming mechanism. The roaming mechanism was first proposed by van Zee et al. ${ }^{75}$ in a seminal paper on the photolysis of formaldehyde to $\mathrm{CO}$ and $\mathrm{H}_{2}$ : in essence the standard, tight transition state route produced rotationally hot $\mathrm{CO}$ whilst the loose transition state resulted in rotationally cold CO. During the photolysis of acetaldehyde, the formation of a loose transition state allows a roaming mechanism that results in $\mathrm{CH}_{4}$ and cold 
$\mathrm{CO}^{76-78}$, and work by the Klippenstein group ${ }^{79,80}$ shows the same is true for thermal decomposition of $\mathrm{CH}_{3} \mathrm{CHO}$ at $\mathrm{T}>1000 \mathrm{~K}$.

It is not unreasonable to postulate acetaldehyde as an intermediate, however it is difficult to identify from IR spectra in the presence of acetone as it usually appears as a shoulder on the lower frequency of the acetone $1740 \mathrm{~cm}^{-1} \mathrm{C}=\mathrm{O}$ stretch. Further, in our case, it may be present at low steady state concentrations below the detection limit of the equipment. If acetaldehyde is the key intermediate then the following mechanism would explain the observed data.

As per the model proposed by Kim and co-workers ${ }^{73}$, there are two reaction zones, the Macor/plasma interface and the bulk plasma, the chemistry in the latter wholly uninfluenced by the Macor.

In the bulk of the plasma, the formation of both acetaldehyde and acetone takes place via electron impact:

$$
\begin{gathered}
\mathrm{CH}_{3} \mathrm{CHOHCH}_{3}+\mathrm{e}^{-} \rightarrow \mathrm{CH}_{3} \mathrm{CHO}+\mathrm{CH}_{4}+\mathrm{e}^{-} \\
\mathrm{CH}_{3} \mathrm{CHOHCH}_{3}+\mathrm{e}^{-} \rightarrow \mathrm{C}_{3} \mathrm{H}_{7} \mathrm{O}^{+}+\mathrm{H}^{+}+3 \mathrm{e}^{-} \\
\mathrm{C}_{3} \mathrm{H}_{7} \mathrm{O}^{+} \rightarrow \mathrm{CH}_{3} \mathrm{COCH}_{3}+\mathrm{H}^{+}
\end{gathered}
$$

Other decomposition mechanisms are also possible such as reaction with excited metastable $\mathrm{N}_{2}$ (e.g. $\mathrm{A}^{3} \Sigma_{\mathrm{u}}{ }^{+}$) and atomic nitrogen such as in the following reaction: 


$$
\mathrm{CH}_{3} \mathrm{CHOHCH}_{3}+\mathrm{N} \rightarrow \mathrm{C}_{3} \mathrm{H}_{7}+\mathrm{HNO}
$$

Acetone does not react further: in contrast, acetaldehyde may react further, either by electron impact or photoexcitation (nitrogen-fed non-thermal plasmas show significant emission ${ }^{81}$ around the $\lambda_{\max }$ for the dissociation of acetaldehyde of $308 \mathrm{~nm}^{76}$ )

$$
\begin{gathered}
\mathrm{CH}_{3} \mathrm{CHO}+\mathrm{e}^{-} \rightarrow\left[\mathrm{CH}_{3}----\mathrm{CHO}\right]^{\ddagger}+\mathrm{e}^{-}(\text {Loose TS }) \\
\mathrm{CH}_{3} \mathrm{CHO}+\mathrm{h} v \rightarrow\left[\mathrm{CH}_{3}----\mathrm{CHO}^{\ddagger}(\text { Loose TS })\right. \\
{\left[\mathrm{CH}_{3}----\mathrm{CHO}\right]^{\ddagger} \rightarrow \mathrm{CH}_{4}+\mathrm{CO}(\text { cold })(\text { Roaming })} \\
{\left[\mathrm{CH}_{3}--\mathrm{CHO}\right]^{\ddagger} \rightarrow \mathrm{CH}_{3}+\mathrm{CHO}(\text { Tight TS) }}
\end{gathered}
$$

In the absence of the liquid film, i.e. with the Macor surface accessible, acetaldehyde is dehydrated to acetylene, catalysed by aluminium/magnesium oxide sites $^{82}$ on the Macor:

$$
\mathrm{CH}_{3} \mathrm{CHO} \rightarrow \mathrm{HC} \equiv \mathrm{CH}+\mathrm{H}_{2} \mathrm{O}
$$

\section{Conclusions}

Macor does not catalyse any reaction of isopropyl alcohol in dinitrogen at temperatures up to $600^{\circ} \mathrm{C}$. In contrast, it has a very significant effect upon the analogous plasma-driven process. In 
$\mathrm{N}_{2}+$ IPA -fed non-thermal plasma, two reaction zones are established: one at the Macor/plasma interface where the Macor catalyses the formation of a brown oil containing a polymethylacetylene-like polymer also (probably) bearing nitrogen containing functionality, and isophorone. This oil eventually blocks the Macor surface preventing further reactions of this nature. The second zone is in the bulk of the plasma, remote from the Macor. In this zone, CO at a rotational temperature $<<200 \mathrm{~K}$ and $\mathrm{CH}_{4}, \mathrm{HCN}$ and acetone are also produced. Electron impact of the IPA results in acetone and acetaldehyde production: the former does not react further. In contrast, the acetaldehyde is excited to form a loose transition state via electron impact or photo-excitation from the plasma emission: this results in the dissociation of the acetaldehyde to $\mathrm{CH}_{4}$ and cold $\mathrm{CO}$ via a roaming reaction. Replacing the dinitrogen by argon completely inhibits the formation of the oil, leaving the Macor surface clear, and this now catalyses the formation of acetylene.

\section{Associated Content \\ SI Supporting Information}

(a) A photograph and (b) schematic of the in-situ FTIR non thermal plasma cell (Figure S1), Comparison the spectra of gas phase IPA and an authentic sample of liquid IPA. The former was obtained using the plasma transmission cell, and the latter as a thin layer pressed between the $\mathrm{CaF}_{2}$ windows of a Thermo Scientific Presslok demountable cell holder (Figure S2), The spectrum collected at 27W in Figure 1(a) and that of $13.4 \% \mathrm{CH}_{4}+10.6 \% \mathrm{CO}_{2}+76.0 \% \mathrm{~N}_{2}$ in the plasma transmission cell (Figure S3), A spectrum of (i) gas phase acetone obtained in the plasma transmission cell and (ii) the spectrum in Figure 2(b): (a) full spectral range and (b) $900-2000$ 
$\mathrm{cm}^{-1}$. The acetone spectrum was reduced by a factor of 3.9 (Figure S4), (i) The CO spectral region of Figure $\mathrm{S} 3$ and (ii) that of a spectrum collected of $100 \% \mathrm{CO}$ in a $1 \mathrm{~cm}$ pathlength transmission cell at $298 \mathrm{~K}$. The spectrum in (ii) has been scaled down by a factor of 15.7 (Figure S5), In-situ FTIR absorbance spectra (100 co-added scans and averaged scans at $4 \mathrm{~cm}^{-1}$ resolution, ca. 100 seconds per scan set) collected during the plasma treatment of IPA at $27 \mathrm{~W}$ as a function of plasma operation time. The $\mathrm{N}_{2}$ gas flow rate was $200 \mathrm{~cm}^{3} \mathrm{~min}^{-1}$, bubbled through a Dreschel bottle of pure IPA at room temperature (Figure S6), Plots of the intensities of the 2164 $\mathrm{cm}^{-1} \mathrm{CO}$ band and the $1740 \mathrm{~cm}^{-1}$ acetone band, and the partial pressure of $\mathrm{CO}$, measured after 1 minute plasma operation as a function of input power. The spectra were collected and manipulated as in the experiment shown in Figure 2(a) (Figure S7), Plot of the intensities of the key features in Figure 4 vs time (Figure S8), The spectra collected in Figure 4 up to 8 minutes (Figure S9), The spectrum collected after 8 minutes in Figure 4 subtracted from those taken up to 20 minutes (Figure S10), and IR spectrum of ca. $50 \mu \mathrm{L}$ isophorone obtained as a thin layer pressed between the $\mathrm{CaF}_{2}$ windows of a Thermo Scientific Presslok demountable cell holder (Figure S11).

\section{Author Information}

\section{Corrresponding Author}

Paul A. Christensen ${ }^{* a}$

E-mail: paul.christensen@ncl.ac.uk

Address: School of Engineering, Bedson Building, Newcastle University, Newcastle upon Tyne, NE1 7RU, UK. 


\section{Author Contributions}

The manuscript was written through contributions of all authors. All authors have given approval to the final version of the manuscript.

\section{Funding Sources}

The authors declare no competing financial interest.

\section{Acknowledgements}

Abd Halim Bin Md Ali would like to thank the Government of Malaysia for a scholarship to study for a Ph. D, the staff of the Majlis Amanah Rakyat in Kuala Lumpur, Malaysia and London, United Kingdom for their invaluable assistance. Z. T. A. W. Mashhadani would like to thank the Government of Iraq for a Scholarship, the staff of the Higher Committee for Education Development in Iraq for their invaluable assistance and the Iraq Ministry of Oil Petroleum Research and Development Center PRDC for the opportunity to study for a Ph. D. The authors also wish to thank Mr. Neville Dickman for his assistance and support for this work and Prof. Bernard Golding for helpful discussions.

\section{References}

1. Gicquel, A.; Cavadias, S.; Amouroux, J. Heterogeneous Catalysis in Low-Pressure Plasmas. J. of Phys. D: Appl. Phys. 1986, 19, 2013-2042.

2. Bahri, M.; Haghighat, F. Plasma-Based Indoor Air Cleaning Technologies: The State of the Art-Review. CLEAN-Soil, Air, Water 2014, 42, 1667-1680. 
3. Manley, T. C. The Electric Characteristics of the Ozonator Discharge. ECST 1943, 84, 83-96.

4. Nozaki, T.; Muto, N.; Kado, S.; Okazaki, K. Dissociation of Vibrationally Excited Methane on Ni Catalyst: Part 1. Application to Methane Steam Reforming. Cat. Today 2004, 89, 57-65.

5. Langleron, M.; Cavadias, S.; Amouroux, J. Study by Mass Spectrometry and Gas Chromatography of Toluene Oxidation in a Low-Pressure Plasma Reactor. Rapid Commun. Mass Sp. 1995, 9, 18-22.

6. Jeong, J. Y.; Park, J.; Henins, I.; Babayan, S. E.; Tu, V. J.; Selwyn, G. S.; Hicks, R. F. Reaction Chemistry in the Afterglow of an Oxygen- Helium, Atmospheric-Pressure Plasma. $J$ Phys Chem A 2000, 104, 8027-8032.

7. Kasinathan, P.; Park, S.; Choi, W. C.; Hwang, Y. K.; Chang, J. S.; Park, Y. K. PlasmaEnhanced Methane Direct Conversion Over Particle-Size Adjusted $\mathrm{MOx} / \mathrm{Al}_{2} \mathrm{O}_{3}(\mathrm{M}=\mathrm{Ti}$ and $\mathrm{Mg})$ Catalysts. Plasma Chem Plasma P. 2014, 34, 1317-1330.

8. Thejaswini, H. C.; Peglow, S.; Sushkov, V.; Hippler, R. Infrared Spectroscopy of $\mathrm{CH}_{4} / \mathrm{N}_{2}$ and $\mathrm{C}_{2} \mathrm{H}_{\mathrm{m}} / \mathrm{N}_{2}(\mathrm{~m}=2,4,6)$ Gas Mixtures in a Dielectric Barrier Discharge. Plasma Chem Plasma P. 2014, 34, 1157-1170.

9. Whitehead, J. C. Plasma-Catalysis: The Known Knowns, The Known Unknowns and The Unknown Unknowns. J Phys D Appl Phys. 2016, 49, 243001 (24pp). 
10. Chen, H. L.; Lee, H. M.; Chen, S. H.; Chang, M. B. Review of Packed-Bed Plasma Reactor for Ozone Generation and Air Pollution Control. Ind Eng Chem Res. 2008, 47, 21222130.

11. Fridman, A. Plasma Chemistry; Cambridge University Press: New York, 2008, p263.

12. Aerts, R.; Somers, W.; Bogaerts, A. Carbon Dioxide Splitting in a Dielectric Barrier Discharge Plasma: a Combined Experimental and Computational Study. ChemSusChem. 2015, 8, $702-716$.

13. Martuzevicius, D.; Denafas, G.; Stasiulaitienè, I.; Abromaitis, V.; Ochmanaitè, V; Krugly, E.; Prasauskas, T. Report on Eco-Efficiency of Plasma-Based Technologies for Environmental Protection, Kaunas 2011, http://www.plastep.eu/fileadmin/dateien/Outputs/OP32.1_Eco-efficiency report.pdf.

14. Hammer, T. Atmospheric Pressure Plasma Application for Pollution Control in Industrial Processes. Contrib Plasm Phys. 2014, 54, 187 - 201.

15. Kogelschatz, U. Dielectric-Barrier Discharges: Their History, Discharge Physics, and Industrial Applications. Plasma Chem Plasma P. 2003, 23, 1 - 46

16. Malik, M. A.; Hughes, D.; Heller, R.; Schoenbach, K. H. Surface Plasmas Versus Volume Plasma: Energy Deposition and Ozone Generation in Air and Oxygen. Plasma Chem Plasma P. 2015, 35, $697-704$.

17. Zhang, K.; Mukhriza, T.; Liu, X.; Greco, P. P.; Chiremba, E. A study on $\mathrm{CO}_{2}$ and $\mathrm{CH}_{4}$ Conversion to Synthesis Gas and Higher Hydrocarbons by the Combination of Catalysts and Dielectric-Barrier Discharges. Appl Catal A Gen .2015, 502, 138-149. 
18. Nguyen, V. N.; Blum, L. Syngas and Synfuels From $\mathrm{H}_{2} \mathrm{O}$ and $\mathrm{CO}_{2}$ : Current Status. Chem Ing Tech. 2015, 87, $354-375$.

19. Xiao, G.; Xu, W.; Wu, R.; Ni, M.; Du, C.; Gao, X.; Luo, Z.; Cen, K. Non-Thermal Plasmas For Vocs Abatement. . Plasma Chem Plasma P. 2014, 34, 1033 - 1065

20. Scholtz, V.; Pazlarová, J.; Soušková, H.; Khuna, J.; Julá, J. Nonthermal Plasma-A Tool for Decontamination and Disinfection. Biotechnol Adv. 2015, 33, 1108-1119.

21. Lili, B. A. N.; Ping, L. I. U.; Cunhua, M. A.; Bin, D. A. I. Deep Desulfurization of Diesel Fuels With Plasma/Air as Oxidizing Medium, Diperiodatocuprate (III) as Catalyzer and Ionic Liquid as Extraction Solvent. Plasma Sci Technol. 2013, 15(12), 1226-1231.

22. Bai1, M.; Leng, B.; Mao, S.; Li, C. Flue Gas Desulfurization by Dielectric Barrier Discharge. Plasma Chem Plasma P. 2016, 36, 511 - 521.

23. Ashford, B.; Tu, X. Non-Thermal Plasma Technology for the Conversion of $\mathrm{CO}_{2}$. Curr Opin Environ Sustain. 2017, 3, 45 - 49.

24. Scarduelli, G.; Guella, G.; Ascenzi, D.; Tosi, P. Synthesis of liquid organic compounds from $\mathrm{CH}_{4}$ and $\mathrm{CO}_{2}$ in a dielectric barrier discharge operating at atmospheric pressure. Plasma Process Polym. 2011, 8, 25 - 31.

25. Zeng, Y.; Zhu, X.; Mei, D.; Ashford, B.; Tu, X. Plasma-Catalytic Dry Reforming of Methane Over $\gamma-\mathrm{Al}_{2} \mathrm{O}_{3}$ Supported Metal Catalysts. Catal Today 2015, 256, $80-87$.

26. De Bie, C.; van Dijk, J.; Bogaerts, A. The Dominant Pathways for the Conversion of Methane into Oxygenates and Syngas in an Atmospheric Pressure Dielectric Barrier Discharge. $J$ Phys Chem C 2015, 119, $22331-22350$. 
27. http://www.nap.edu/catalog/11960/plasma-science-advancing-knowledge-in-the-nationalinterest p29-32.

28. Neyts, E. C. Plasma-Surface Interactions in Plasma Catalysis. Plasma Chem Plasma P. 2016, 36, pp.185 - 212 .

29. Havran, V.; Dudukovic, M. P.; Lo, C. L. Conversion of Methane and Carbon Dioxide to Higher Value Products. Ind Eng Chem Res. 2011, 50, 7089 - 7100.

30. Abd Allah, Z.; Whitehead, J. C.; Martin, P. Remediation of Dichloromethane $\left(\mathrm{CH}_{2} \mathrm{Cl}_{2}\right)$ Using Non-Thermal, Atmospheric Pressure Plasma Generated in a Packed-Bed Reactor. Environ Sci Technol. 2013, 48, 558-565.

31. Kozák, T.; Bogaerts, A. Splitting of $\mathrm{CO}_{2}$ by Vibrational Excitation in Non-Equilibrium Plasmas: a Reaction Kinetics Model. Plasma Sources Sci T. 2014, 23, 045004 (17pp).

32. Sakiyama, Y.; Graves, D. B.; Chang, H. W.; Shimizu, T.; Morfill, G. E. Plasma Chemistry Model of Surface Microdischarge in Humid Air and Dynamics of Reactive Neutral Species. J Phys D Appl Phys. 2012, 45, 425201 (19pp).

33. Al-Abduly, A.; Christensen, P. A. An In Situ and Downstream Study of Non-Thermal Plasma Chemistry in an Air Fed Dielectric Barrier Discharge (DBD). Plasma Sources Sci T. 2015, 24, 065006 (16pp).

34. Christensen, P. A.; Attidekou, P. S.; Egdell, R. G.; Maneelok, S.; Manning, D. A. C. An In Situ FTIR Spectroscopic And Thermogravimetric Analysis Study of the Dehydration and Dihydroxylation of $\mathrm{SnO}_{2}$ : the Contribution of the (100),(110) and (111) Facets. Phys Chem Chem Phys. 2016, 18, 22990-22998. 
35. https://psec.uchicago.edu/ceramics/MACOR\%20Data\%20Sheet.pdf.

36. Subrahmanyam, C.; Renken, A.; Kiwi-Minsker, L. Novel Catalytic Dielectric Barrier Discharge Reactor for Gas-Phase Abatement of Isopropanol. Plasma Chem Plasma P. 2007, 27, $13-22$.

37. Jarrige J.; Vervisch, P. Plasma-Enhanced Catalysis of Propane and Isopropyl Alcohol at Ambient Temperature on a $\mathrm{MnO}_{2}$-Based Catalyst. Appl Catal B 2009, 90, 74 - 82.

38. Leclerq, J.; Giraud, F.; Bianchi, D.; Fiaty, F.; Gaillard, F. Plasma-assisted Catalysis for the Abatement of Isopropyl Alcohol over Metal Oxides. Appl Catal B 2014, 146, 131 - 137.

39. Miyata, H.; Wakamiya, M.; Kubokawa, Y. Infrared Studies of Interaction Of Oxygen With 2-Propanol and Acetone Adsorbed on MgO and NiO. J Catal. 1974, 34, 117-123.

40. Koga, O.; Onishi, T.; Tamaru, K. Adsorption and Decomposition of Isopropyl Alcohol Over Zinc Oxide. Infrared and Kinetic Study. J. Chem. Soc. Faraday Trans. 1 1980, 76, 19 - 29.

41. Rossi, P. F.; Busca, G.; Lorenzelli, V.; Saur, O.; Lavalley, J. C. Microcalorimetric and FT-IR Spectroscopic Study of the Adsorption of Isopropyl Alcohol and Hexafluoroisopropyl Alcohol on Titanium Dioxide. Langmuir 1987, 3, 52 - 58.

42. Hussein, G. A. M.; Sheppard, N.; Zaki, M. I.; Fahim, R. B. Infrared Spectroscopic Studies of the Reactions of Alcohols Over Group IVB Metal Oxide Catalysts. Part 1.-Propan-2ol Over $\mathrm{TiO}_{2}, \mathrm{ZrO}_{2}$ and $\mathrm{HfO}_{2}$. J. Chem. Soc. Faraday Trans. 1 1989, 85, $1723-1741$.

43. Resini, C.; Montanari, T.; Busca, G.; Jehng, J-M.; Wachs, I. E. Comparison of Alcohol and Alkane Oxidative Dehydrogenation Reactions Over Supported Vanadium Oxide Catalysts: 
In Situ Infrared, Raman and UV-Vis Spectroscopic Studies of Surface Alkoxide Intermediates and of Their Surface Chemistry. Catal Today 2005, 99, 105-114.

44. Arsac, F.; Bianchi, D.; Chovelon, J. M.; Ferronato, C.; Herrmann, J. M. Experimental Microkinetic Approach of the Photocatalytic Oxidation of Isopropyl Alcohol on TiO2. Part 1. Surface Elementary Steps Involving Gaseous and Adsorbed $\mathrm{C}_{3} \mathrm{H}$ x O Species. $J$ Phys Chem A 2006, $110,4202-4212$.

45. Xu, W.; Raftery, D.; Francisco, J. S. Effect of Irradiation Sources and Oxygen Concentration on the Photocatalytic Oxidation of 2-Propanol and Acetone Studied by In Situ FTIR. J Phys Chem B 2003, 107, 4537 - 4544.

46. Fuentea, S. A.; Ferrettib, C. A.; Domancicha, N. F.; Díezb, V. K.; Apesteguíab, C. R.; Di Cosimob, J. I.; Ferulloc, R. M.; Castellani, N. J. Adsorption of 2-Propanol on MgO Surface: A Combined Experimental and Theoretical Study. Appl Surf Sci. 2015, 327, 268-276.

47. Schmidt-Bleker, A.; Winter, J.; Iseni1, S.; Dünnbier, M.; Weltmann, K-D.; Reuter, S. Tracking Plasma Generated $\mathrm{H}_{2} \mathrm{O}_{2}$ From Gas Into Liquid Phase and Revealing Its Dominant Impact on Human Skin Cells. J Phys D Appl Phys. 2014, 47, 145201 (12pp).

48. Rivallan, M.; Fourré, E.; Aiello, S.; Tatibouët, J-M.; Thibault-Starzyk, F. Insights into the Mechanisms of Isopropanol Conversion on $\gamma-\mathrm{Al}_{2} \mathrm{O}_{3}$ By Dielectric Barrier Discharge. Plasma Process Polym. 2012, 9, 850-854.

49. Li, K.; Gabriel, O.; Meichsner, J. Fourier Transform Infrared Spectroscopy Study of Molecular Structure Formation in Thin Films during Hexamethyldisiloxane Decomposition in Low Pressure Rf Discharge. Journal of Physics D: Applied Physics 2004, 37, 588 - 594. 
50. Stere, C. E.; Adress, W.; Burch, R.; Chansai, S.; Goguet, A.; Graham, W. G.; Hardacre, C. Probing a Non-Thermal Plasma Activated Heterogeneously Catalyzed Reaction Using In Situ DRIFTS-MS. ACS Catal. 2015, 5, 956 - 964.

51. Rodrigues, A.; Tatibouët, J-M.; Fourré, E. Operando DRIFT Spectroscopy Characterization of Intermediate Species on Catalysts Surface in VOC Removal from Air by Non-thermal Plasma Assisted Catalysis. Plasma Chem Plasma P. 2016, 36, 901 - 905.

52. Jia, Z.; Rousseau, A. Sorbent Track: Quantitative Monitoring of Adsorbed VOCs Under In-Situ Plasma Exposure. Nature Scientific reports 2016, 6, 31888, 1 - 11.

53. Rivallan, M.; Aiello, S.; Thibault-Starzyk, F. Operando DRIFT Spectroscopy Characterization of Intermediate Species on Catalysts Surface in VOC Removal from Air by Non-thermal Plasma Assisted Catalysis. Rev. Sci. Instrum. 2010, 81, 103111(4 pp).

54. Barakat, C.; Gravejat, P.; Guaitella, O.; Thevenet, F.; Rousseau, A. Oxidation of Isopropanol and Acetone Adsorbed on $\mathrm{TiO}_{2}$ Under Plasma Generated Ozone Flow: Gas Phase and Adsorbed Species Monitoring. Appl Catal B 2014, 147, 302- 313.

55. P. A. Christensen, Abd Halim Bin Md Ali, Z. T. A. W. Mashhadani and P. A. Martin, A Direct Fourier Transform Infrared Spectroscopic Comparison of the Plasma- and ThermallyDriven Reaction of $\mathrm{CO}_{2}$ at Macor. Plasma Chem Plasma Process, 2018, 38: 293-310.

56. Choi, K. N.; Barker, E. F. Infrared Absorption Spectrum of Hydrogen Cyanide. Phys. Rev. 1932, 42, 777-785.

57. Mehrotra, R. C.; Batwara, J. M. Preperation and Reactions of Alkoxides of Gadolinium and Erbium. Inorg Chem. 1970, 9, 2595 - 2510. 
58. Herzberg, G., Infrared and Raman Spectra of Polyatomic Molecules; D. Van Nostrand Company: New York, 1945, pp $306-307$.

59. Dellepiane, G.; Overend, J. Vibrational Spectra and Assignment of Acetone, $\alpha \alpha \alpha$ Acetone-d3 and Acetone-d6. Spectrochim Acta. 1966, 22, 593 - 614.

60. Luyben, W. L. Design and Control of the Acetone Process via Dehydrogenation of 2Propanol. Ind Eng Chem Res. 2011, 50, 1206 - 1218.

61. Rioux, M.; Vannice, M. A. Hydrogenation/Dehydrogenation Reactions: Isopropanol Dehydrogenation over Copper Catalysts. J Catal. 2003, 216, 362 - 376.

62. Said, A. E-A. A.; El-Wahib, M. M. M. A.; Goda, M. N. Selective Synthesis of Acetone from Isopropyl Alcohol Over Active and Stable CuO-NiO Nanocomposites at Relatively LowTemperature. Egy J Basic Appl Scis. 2016, 3, 357 - 365.

63. Halwy, S. A.; Mohamed, M. A.; El-Hafez, S. F. A. Dehydrogenation of Isopropyl Alcohol over Co Ni/Mg Oxide Catalysts. J Mol Catal. 1994, 94, 191 - 201.

64. Tsang, C. W.; Harrison, A. G. Concerning the Structure and Fragmentation of $\left[\mathrm{C}_{3} \mathrm{H}_{7} \mathrm{O}\right]+$ Ions Derived from Alcohols. Journal of Mass Spectrometry 1971, 5, 877 - 884.

65. Bauerecker, S.; Taraschewski, M.; Weitkamp, C.; Cammenga, H. K. Liquid-Helium Temperature Long-Path Infrared Spectroscopy of Molecular Clusters and Supercooled Molecules. Rev Sci Instrum. 2001, 72, 3946 - 3955.

66. Herzberg, G. Molecular Spectra and Molecular Structure: I Spectra of Diatomic Molecules, 2nd Edn., Van Nostrand, New York, 1950, 126 - 127. 
67. Cataldo, F. Synthesis of Ketonic Resins from Self-Polymerization of Acetone, 1. Action of Protic and Lewis Acids on Acetone. Macromol Mater Eng. 1996, 236, 1-19.

68. Cataldo, F. Synthesis of Ketonic Resins from Self-Polymerization of Acetone, 2. Action Of Bases On Acetone And The Synthesis Of Halogenated And Diels-Alder Adducts. Macromol Mater Eng. 1996, 236, 21-33.

69. Peluso, A.; Seel, M.; Ladik, J. The Infrared and Raman Spectrum of Trans-Polyacetylene: A Self-Consistent-Field Study. Solid state commun. 1985, 53, 893 - 896.

70. Trinh, H. Q.; Mok, Y. S. Plasma-Catalytic Oxidation of Acetone in Annular Porous Monolithic Ceramic-Supported Catalysts. Chem Eng J. 2014, 251, 199 - 206.

71. Manríquez, M. E.; Hernández-Cortez, J. G.; Wang, J. A.; Chen, L. F.; Zuñiga-Moreno, A.; Gómez, R. Synthesis of Transition Metal Doped Lamellar Double Hydroxides As Base Catalysts for Acetone Aldol Condensation. Appl Clay Sci. 2015, 118, 188-194.

72. Giguère, P. A.; Harvey, K. B. On the Infrared Absorption of Water and Heavy Water in Condensed States. Can J Chem. 1956, 34, 798-808.

73. Kim, H-H.; Teramoto, Y.; Negishi, N.; Ogata, A. A Multidisciplinary Approach to Understand the Interactions of Nonthermal Plasma and Catalyst: A Review. Catal Today 2015, $256,13-22$.

74. Stein, S. E. "Infrared Spectra", NIST Chemistry WebBook, in NIST Standard Reference Database Number 69, Eds. P.J. Linstrom and W.G. Mallard, National Institute of Standards and Technology, Gaithersburg MD, 8860, http://webbook.nist.gov, (retrieved 24 October 2017). 
75. Van Zee, R. D.; Holtz, M. F.; Moore, C. B. Evidence for A Second Molecular Channel in the Fragmentation of Formaldehyde. J Chem Phys. 1993, 99, 1664-1673.

76. Heazlewood, B. R.; Jordan, M. J. T.; Kable, S. H.; Selby, T. M.; Osborn, D. L.; Shepler, B. C.; Braams, B. J.; Bowman, J. M. Roaming is the Dominant Mechanism for Molecular Products in Acetaldehyde Photodissociation. Proc Natl Acad Sci USA 2008, 105, 12719-12724.

77. Bowman, J. M. Skirting the Transition State, a New Paradigm in Reaction Rate Theory. Proc Natl Acad Sci USA 2006, 103, 16079 - 16082.

78. Houston, P. L.; Cable, S. H. Proc Natl Acad Sci USA 2006, 103, 16061 - 16062.

79. Sivaramakrishnan, R.; Michael, J. V.; Klippenstein, S. J. Direct Observation of Roaming Radicals in the Thermal Decomposition of Acetaldehyde. J Phys Chem A 2010, 114, 755-764.

80. Harding, L. B.; Georgievskii, Y.; Klippenstein, S. J. Roaming Radical Kinetics in the Decomposition of Acetaldehyde. J Phys Chem A 2010, 114, 765 - 777.

81. Xiao, D.; Cheng, C.; Shen, J.; Lan, Y.; Xie, H.; Shu, X.; Meng, Y.; Li, J.; Chu, P. K. Characteristics of Atmospheric-Pressure Non-Thermal $\mathrm{N}_{2}$ And $\mathrm{N}_{2} / \mathrm{O}_{2}$ Gas Mixture Plasma Jet. $J$. Appl. Phys. 2014, 115, 033303 (10pp).

82. Everett, C. Acetaldehyde Dehydration to Produce Ethyne, US 0102647 A1, May 27 2004.

TOC Graphic

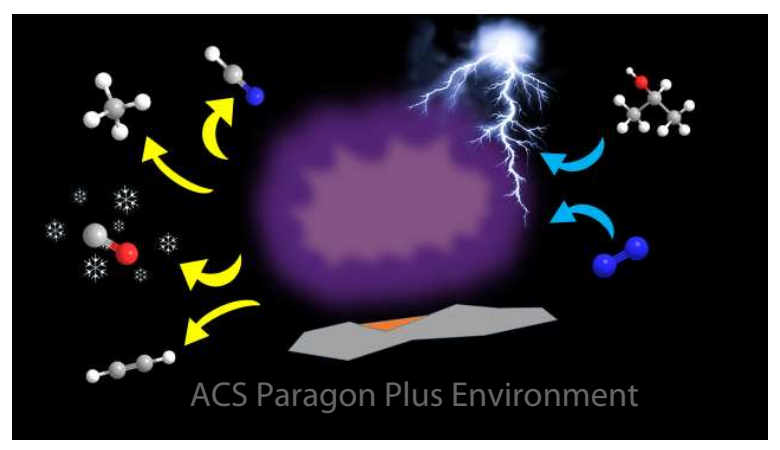


